\title{
APPLICATION OF THE ELECTRE TRI METHOD FOR SUPPLIER CLASSIFICATION IN SUPPLY CHAINS
}

\author{
Anderson Tiago Peixoto Gonçalves ${ }^{1 *}$, Maria Valéria Pereira de Araújo ${ }^{2}$, \\ Anderson Luiz Rezende Mól $^{3}$ and Fabrícia Abrantes Figueiredo da Rocha ${ }^{4}$
}

Received June 2, 2020 / Accepted December 11, 2020

\begin{abstract}
The present research aims to propose a Supplier Selection Model that creates collaborative relationships in Supply Chains, so that suppliers can be previously categorized into the cooperation, the coordination and the collaboration levels. Applied, quantitative, exploratory and descriptive research methods were used. A bibliographical research, a questionnaire, and the quantitative modeling were adopted as methodological procedures. The managers responsible for the Supplier Selection process in the Brazilian Wind Energy companies participated in this research. First, a criteria framework for the Selection of Supplier of goods and services was developed. Second, a Multicriteria Decision Aiding Model was created and validated, enabling the classification of the suppliers according to the relationship levels in a systematic way in terms of their performance from a set of criteria by implementing the ELECTRE TRI method. Firms can use the Model periodically in order to revise the supplier assessment and, if needed, direct them to either an inferior or superior class.
\end{abstract}

Keywords: supply chain, multicriteria decision, ELECTRE TRI.

\section{INTRODUCTION}

In today's world firms operate in an environment where they need to do business differently if they intend to stay competitive. In the past few decades, they have faced this challenge by implementing Collaborative Supply Chains that allows them to maintain and gain competitive advantages through collaborative efforts with their suppliers and customers (Cao et al., 2010; Cao \& Zhang, 2011; Chan, Chong \& Zhou, 2012; Lehoux, D’Amours \& Langevin, 2014; Gomes

\footnotetext{
*Corresponding author

${ }^{1}$ Universidade Federal de Pernambuco (UFPE), PE, Brasil - E-mail: adm.andersontiago@gmail.com https://orcid.org/0000-0002-7338-2180

${ }^{2}$ Universidade Federal do Rio Grande do Norte (UFRN), RN, Brasil - E-mail: valeriaaraujoufrn@gmail.com https://orcid.org/0000-0001-6302-1173

${ }^{3}$ Universidade Federal do Rio Grande do Norte (UFRN), RN, Brasil - E-mail: mol.ufrn@gmail.com https://orcid.org/0000-0001-5915-8070

${ }^{4}$ Instituto Federal de Educação, Ciência e Tecnologia do Rio Grande do Norte (IFRN), RN, Brasil - E-mail: fabricia.rocha@ifrn.edu.br - https://orcid.org/0000-0001-9924-7334
} 
\& Kliemann Neto, 2015; Hui, Cheng \& Fei, 2015; Soosay \& Hyland, 2015; Liao, Hu \& Ding, 2017; Ralston, Richey \& Grawe, 2017; Salam, 2017; Panahifar et al., 2018; Zhang \& Cao, 2018; Ma, Pal \& Gustafsson, 2019).

The Collaborative Supply Chain consists of two or more independent firms that work together in order to plan and achieve operations of the Supply Chain with greater success as opposed to when they work individually (Simatupang \& Sridharan, 2002).

However, collaboration is only one of the interaction levels among the Supply Chain members. That is, it is the ultimate goal of the phases through which a relationship can evolve, starting with cooperation, flowing into coordination, and eventually achieving collaboration (Spekman, Kamauff Jr \& Myhr, 1998; Backstrand, 2007; Harrison, Hoek \& Skipworth, 2014).

Firms must limit their collaborative relationships to a small yet potentially critical number of strategic customers and suppliers. Thus, they should focus on a small number of close relationships rather than collaborate with everyone (Barratt, 2004).

When it comes to the relationship with the suppliers, it is necessary that firms choose the ones who meet the requirements that allow the creation of collaborative relationships, because they interact with a variety of suppliers that have different characteristics and behaviors; hence, dealing with different relationship levels (Matopoulos et al., 2007).

In this context Supplier Selection is seen as one of the most critical activities in the Supply Chain, since it enables the selection of suppliers who have adequate characteristics for building collaborative relationships with (Viana \& Alencar, 2012; Lima Junior, Osiro \& Carpinetti, 2013; Yildiz \& Yayla, 2017; Chang, 2019).

Therefore, the present research aims to propose a Supplier Selection Model in order to build collaborative relationships in Supply Chains, so that suppliers can be previously categorized into the cooperation, the coordination and the collaboration levels.

Supplier Selection has been predominantly seen as a decision-making problem with multiple qualitative and quantitative criteria that can be extremely conflicting; thus, it requires suitable methods for understanding it (Ho, Xu \& Dey, 2010; Agarwal et al., 2011; Almeida, 2011; Viana \& Alencar, 2012; Chai, Liu \& Ngai, 2013; Lima Junior, Osiro \& Carpinetti, 2013; De Felice et al., 2015; Guarnieri, 2015; Igoulalene, Benyoucef \& Tiwari, 2015; Karsak \& Dursun, 2015; Lima Junior \& Carpinetti, 2015; Sultana, Ahmed \& Azeem, 2015; Yadav \& Sharma, 2015; Yildiz \& Yayla, 2015; Yadav \& Sharma, 2016; Çakir, 2017; Yildiz \& Yayla, 2017; Sarkar, Pratihar \& Sarkar, 2018; Chang, 2019).

For that reason the Multicriteria Decision Aiding Approach was used in order to carry out this research, because it seeks to systematize and organize the supplier selection by supporting the Managers and reducing the decisions made solely based on experience. Its Methods have been widely implemented in various research fields, mostly for structuring decision-making problems with multiple criteria, or conflicting and poorly structured objectives (Gomes \& Gomes, 2019; 
Guarnieri, 2015; Igoulalene, Benyoucef \& Tiwari, 2015; Sultana, Ahmed \& Azeem, 2015; Yadav \& Sharma, 2015).

The ELECTRE TRI Method, primarily defined by Yu (1992), was selected, because it proposes to resolve the classification problems (Mousseau \& Slowinski, 1998; Mousseau, Slowinski \& Zielniewicz, 2000; Mousseau, Figueira \& Naux, 2001; Almeida, 2013; Gomes \& Gomes, 2019; Guarnieri, 2015; Govindan \& Jepsen, 2016). Applications of ELECTRE TRI are found in the literature for the classification of postgraduate courses, storages, customer satisfaction, industrial risks, water distribution systems, products in warehouses, organizational performance, educational institutions, organizational change, among others (Miranda \& Almeida, 2003; Costa, Soares \& Oliveira, 2004; Szajubok, Alencar \& Almeida, 2006; Szajubok, Mota \& Almeida, 2006; Costa et al., 2007; Costa, Santafé Júnior \& Haddad, 2007; Trojan \& Morais, 2012; Fontana \& Cavalcante, 2013; Costa et al., 2014; Freitas \& Silva, 2014; Lieggio Júnior et al., 2016; Aquino et al., 2017).

The selection of this Method also took into consideration the tendency found in the literature regarding the Supplier Selection subproblem in order to build collaborative relationships, in which the decision makers have shown a noncompensatory rationality; that is, without trade-off among the criteria, which is a characteristic of the Methods that compose the Outranking Approach (Guarnieri, 2012).

The present research was developed in the Brazilian Wind Energy Sector where, according to the Agência Brasileira de Desenvolvimento Industrial - ABDI (Brazilian Agency of Industrial Development) (2014), the adoption of Collaborative Supply Chain strategies by making partnerships and long-term contracts between the Wind Energy firms and their suppliers has been encouraged. These strategies have substantially contributed to the reduction of gaps in the supply of goods and services, the reduction of costs, and the increase in competition and warranty of supply.

In order to achieve the main goal of this paper, it was necessary to identify the criteria that are commonly used by Wind Energy companies for the Selection of Supplier of goods and services, so that the Multicriteria Decision Aiding Model could be created and validated.

The contribution of the present study lies in the fact that there is no evidence in the literature of works developed in the Wind Energy Sector that aim to create and validate Supplier Selection Models, either using the Multicriteria Decision Aiding Approach or any other. Moreover, not a single study on the use of the Supplier Selection criteria adopted by the firms in this Sector was found in the literature.

Furthermore, the main theoretical constructs on which this research is based were briefly discussed, the methodological procedures used were presented, the findings were shown, and the conclusions were drawn. 


\section{THEORETICAL BACKGROUND}

\subsection{Relationship levels in the Supply Chain}

The Supply Chain relationships were classified by Spekman, Kamauff Jr \& Myhr (1998), Moharana et al. (2012), Backstrand (2007) and Ma, Pal \& Gustafsson (2019). For this research the classification proposed by Marqui, Moura \& Alcântara (2013) was used, which organizes three levels of integration: cooperation, coordination and collaboration.

Figure 1 summarizes the transition phases until they achieve collaboration and some of the practices that characterize it.

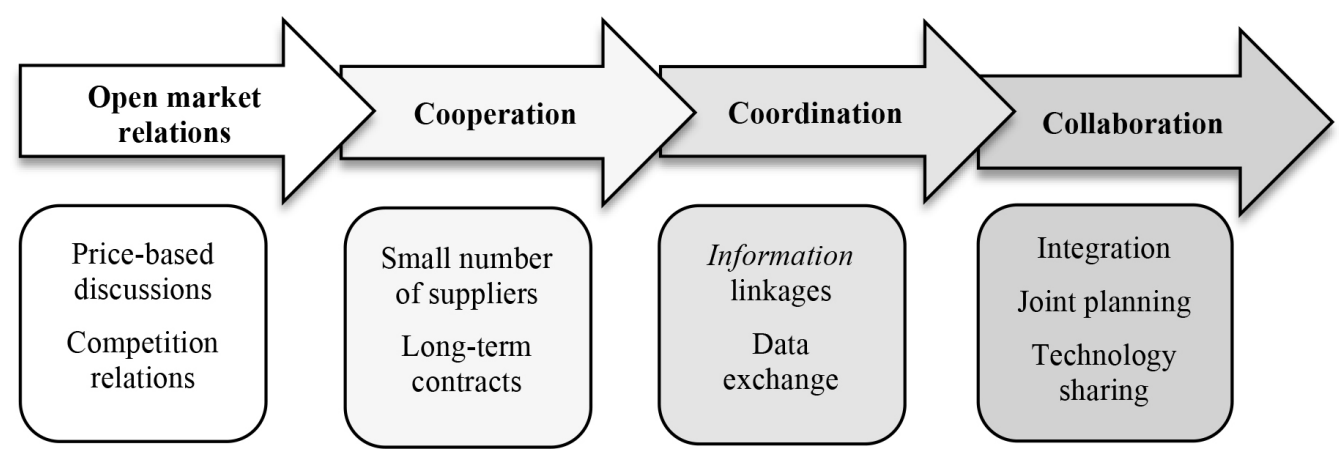

Figure 1 - Transition of open market negotiations to collaboration.

Source: Adapted from Spekman, Kamauff Jr \& Myhr (1998)

According to Harrison, Hoek \& Skipworth (2014), coordination is an essential step to achieve integration in the Supply Chain; whereas collaboration goes beyond that, because it encompasses long-term commitments, sharing of technology and control and planning integrated systems, and interdependence among the firms.

Zacharia, Nix \& Lusch (2009) consider cooperation and collaboration to be different approaches to coordination. Cooperation involves communication and teamwork in order to defuse the tension between individual and common goals. On the other hand, collaboration requires an array of skills and a higher level of joint decisions, information sharing, and establishment of joint goals that can improve shared and individual goals.

In terms of cooperation, firms exchange basic information and build long-term relationships with a limited number of critical suppliers and customers. In terms of coordination, there is a continuous flow of critical and essential information through the use of information technology. In terms of collaboration, there is a high level of commitment, trust and information sharing. Relationships that are strategically important and complex to manage should be treated collaboratively (Spekman, Kamauff Jr \& Myhr, 1998; Singh \& Power, 2009), according to the matrix shown in Figure 2.

Marqui, Moura \& Alcântara (2013) developed a Model that provides the characteristics and the behaviors required on each relationship level, as shown in Figure 3. 


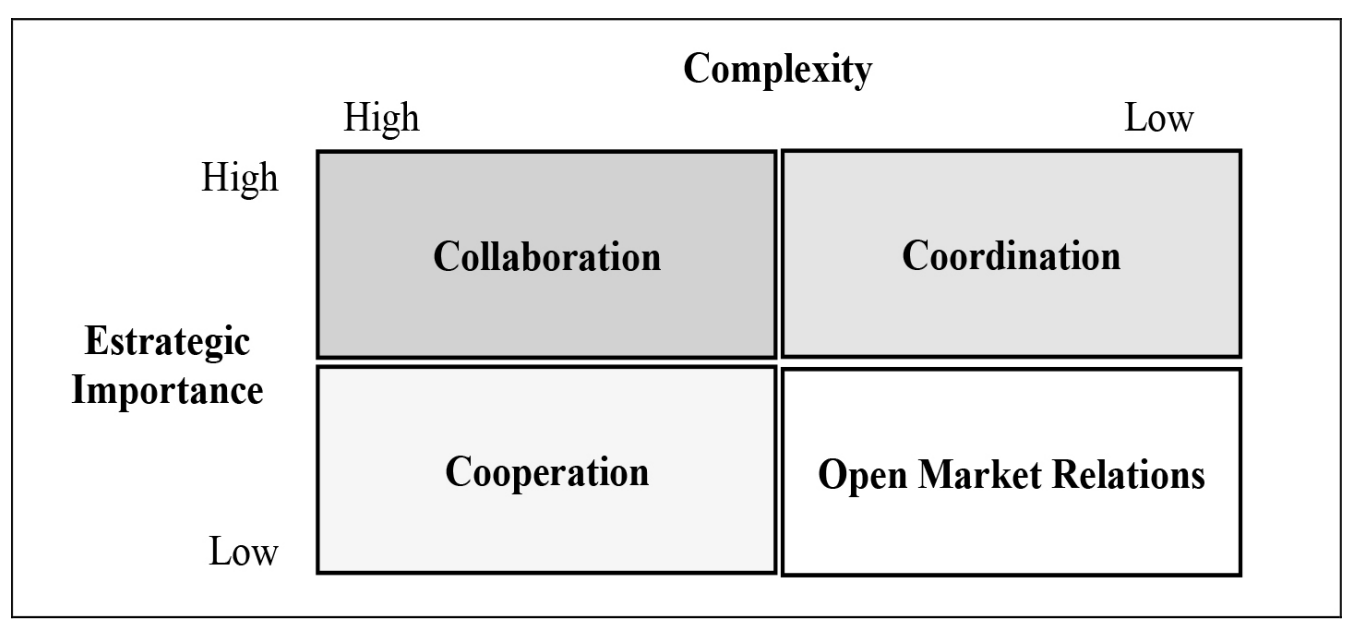

Figure 2 - Strategic importance and relationship complexity in Supply Chains.

Source: Adapted from Spekman, Kamauff Jr \& Myhr (1998).

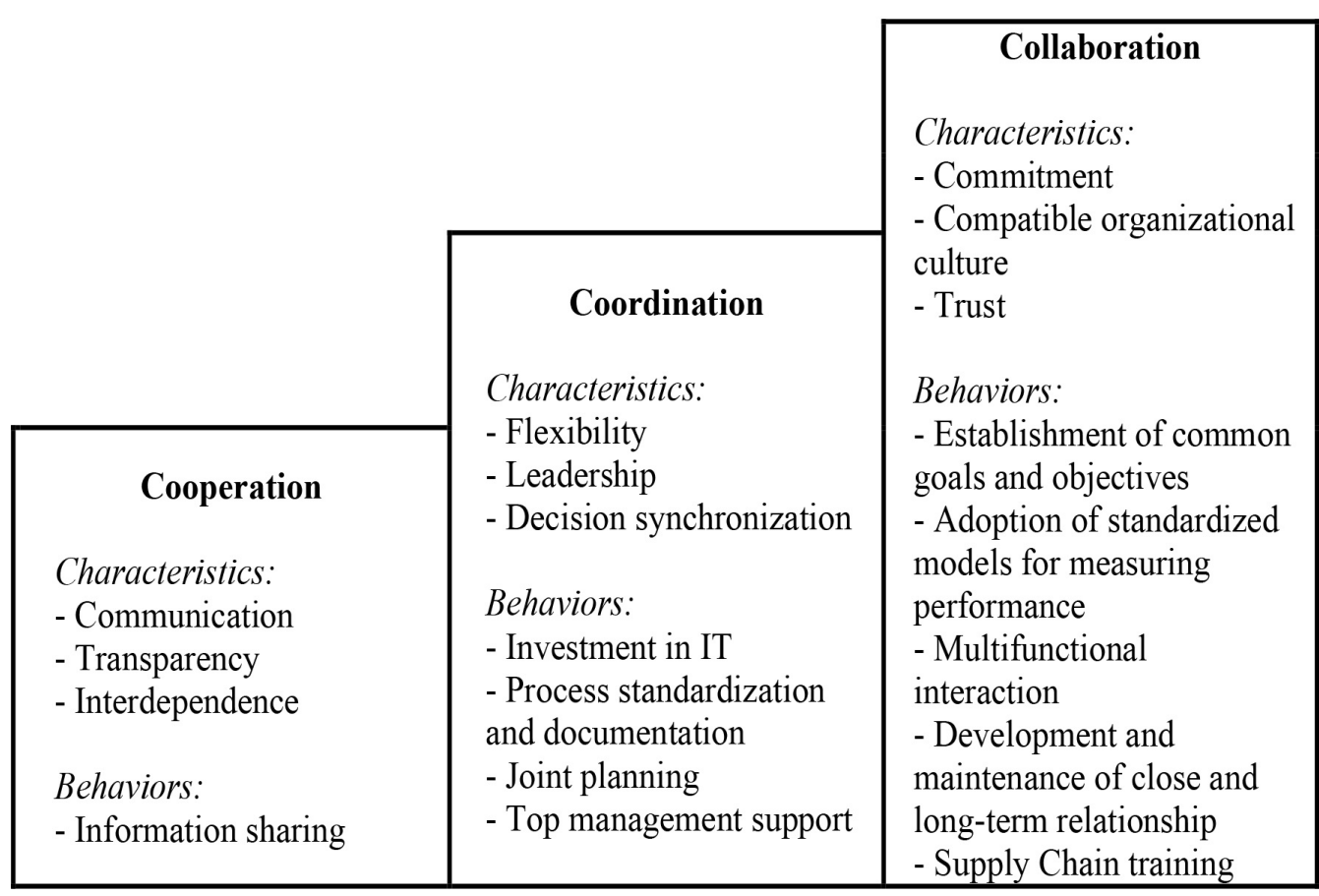

Figure 3 - Stairway to Collaboration.

Source: Adapted from Marqui, Moura \& Alcântara (2013).

A common ground is found in the literature in which the highest level of integration in Supply Chains is collaboration, which is based on a high level of trust; commitment; joint planning and decision; resource, process, information and risk sharing; establishment of mutual objectives; 
and teamwork, so that the goals are achieved and great solutions are found (Zacharia, Nix \& Lusch, 2009; Marqui, Moura \& Alcântara, 2013; Soosay \& Hyland, 2015).

\subsection{Supplier Selection}

For many years the traditional approach for Supplier Selection was based on price as the only decision criterion. Nonetheless, once firms understood that it is not efficient, they started to adopt criteria that involve both quantitative and qualitative factors that are hard to measure due to their subjectivity (Viana \& Alencar, 2012; Lima Junior, Osiro \& Carpinetti, 2013; Pal, Gupta \& Garg, 2013; Guarnieri, 2015; Lima Junior \& Carpinetti, 2015).

Dickson (1966) carried out a groundbreaking study on multiple criteria mapping based on a survey that involved 170 Managers of the purchasing sector in the USA and in Canada, which proposed that the suppliers should be selected according to the 23 criteria shown in Chart 1 .

Chart 1 - Supplier Selection Criteria.

\begin{tabular}{|c|c|c|}
\hline Ranking & Criterion & Evaluation \\
\hline 1 & Quality & Extreme Importance \\
\hline 2 & Delivery & \multirow{7}{*}{ Considerable Importance } \\
\hline 3 & Performance History & \\
\hline 4 & Warranties policies & \\
\hline 5 & Production capacity & \\
\hline 6 & Price & \\
\hline 7 & Technical capability & \\
\hline 8 & Financial position & \\
\hline 9 & Procedural compliance & \multirow{14}{*}{ Average Importance } \\
\hline 10 & Communication system & \\
\hline 11 & Reputation and position in industry & \\
\hline 12 & Desire for business & \\
\hline 13 & Management and organization & \\
\hline 14 & Operating control & \\
\hline 15 & Maintenance and repair service & \\
\hline 16 & Attitude & \\
\hline 17 & Impression & \\
\hline 18 & Packaging ability & \\
\hline 19 & Labor relations record & \\
\hline 20 & Geographical location & \\
\hline 21 & Amount of past business & \\
\hline 22 & Training aids & \\
\hline 23 & Reciprocal arrangements & Slight Importance \\
\hline
\end{tabular}

Source: Adapted from Weber, Current \& Benton (1991). 
Ha \& Krishnan (2008) updated the set of criteria proposed by Dickson (1996), in which the author had not mentioned the after sales service, the technical support, the response to client request, the e-commerce capability, the JIT capability, the ease-of-use, the environmentally friendly products, the product appearance, and technology.

Chart 2 shows the most commonly used criteria for Supplier Selection according to recent works in the literature review.

Chart 2 - Most commonly used criteria for Supplier Selection.

\begin{tabular}{|c|c|}
\hline Author (year) & Criteria \\
\hline Ho, Xu \& Dey (2010) & $\begin{array}{l}\text { Quality; Delivery; Price/cost; Production capacity; } \\
\text { Service; Management; Technology; Research and } \\
\text { Development; Finances; Flexibility; Reputation; } \\
\text { Relationships; Risk; Security and environment. }\end{array}$ \\
\hline Viana \& Alencar (2012) & $\begin{array}{l}\text { Quality; Price; Delivery; Technology capacity; } \\
\text { Production facilities and capacity; Customer service; } \\
\text { Flexibility; Financial position; Geographical location; } \\
\text { Relationship/cooperation capacity; Quality management } \\
\text { practices and systems; Credibility/reputation; } \\
\text { Management and organization; Diversity of items. }\end{array}$ \\
\hline Pal, Gupta \& Garg (2013) & $\begin{array}{l}\text { Price; Quality; Delivery; Performance history; } \\
\text { Warranties and claims policies; Production facilities and } \\
\text { capacity; Technical capability; Financial position; } \\
\text { Procedural compliance; Reputation and position in } \\
\text { Industry; Desire for business; Repair service; Attitude; } \\
\text { Packaging ability; Labor relations record; Geographical } \\
\text { location; Amount of past business; Reciprocal } \\
\text { arrangements. }\end{array}$ \\
\hline Guarnieri (2015) & $\begin{array}{l}\text { Cost; Quality; On-time delivery; Service; Financial } \\
\text { stability; Technology capacity; Late deliveries; Ease of } \\
\text { communication; Response to customer request; } \\
\text { Flexibility; Management and organization; Production } \\
\text { facilities and capacity; Support; Compatible cultures; } \\
\text { Geographical location; Technical and organizational } \\
\text { capabilities; Research and development; Mutual trust. }\end{array}$ \\
\hline Yildiz \& Yayla (2015) & $\begin{array}{l}\text { Quality; Delivery; Cost; Price; Service; Financial status; } \\
\text { Flexibility; Technology; Geographical location; } \\
\text { Technical capability. }\end{array}$ \\
\hline
\end{tabular}

Source: personal compilation (2020).

Guarnieri (2015) emphasizes that Supplier Selection from the perspective of the partnership and the collaborative relationship subproblem, which is the focus of the present research, requires 
specific and less commonly used criteria that involve qualitative factors with a significant level of subjectivity that are hard to measure, such as: buyer commitment, co-design, conflict solution; cooperation; achievement of goals; incentives; innovation; prediction of interactive demand; interorganizational communication; JIT capability; joint action; close relationship; supplier initiative and commitment; supplier development programs; and top management support.

The qualitative criteria that are fundamental for Supplier Selection in partnerships, strategic alliances, and cooperative and collaborative relationships are referenced in the literature as soft factors. These criteria had been primarily discussed by Ellram (1990) who categorized them into four groups, as shown in Chart 3.

Chart 3 - Criteria for supplier partnership selection.

\begin{tabular}{|l|l|}
\hline \multicolumn{1}{|c|}{ Group } & \multicolumn{1}{c|}{ Criteria } \\
\hline Finances & Economic performance; Financial stability. \\
\hline $\begin{array}{l}\text { Organiza- } \\
\text { tional Culture } \\
\text { and Strategy }\end{array}$ & $\begin{array}{l}\text { Feeling of trust; Management attitude/outlook for the future; Strategic } \\
\text { fit; Top management compatibility; Compatibility across levels and } \\
\text { functions of buyer and supplier firms; Supplier's organizational } \\
\text { structure and personnel. }\end{array}$ \\
\hline Technology & $\begin{array}{l}\text { Assessment of current manufacturing facilities/capabilities; } \\
\text { Assessment of future manufacturing capabilities; Supplier's design } \\
\text { capabilities; Supplier's speed in development. }\end{array}$ \\
\hline Others & $\begin{array}{l}\text { Safety record of the supplier; Business references; Supplier's customer } \\
\text { base. }\end{array}$ \\
\hline
\end{tabular}

Source: Adapted from Ellram (1990).

In addition to the work developed by Ellram (1990), Furtado (2005) developed a list of criteria by classifying them in five groups, as shown in Chart 4.

In conclusion, Hudnurkar, Rathod \& Jakhar (2016) found that the following criteria were adopted by Managers in multinational and manufacturing firms for supplier classification in Collaborative Supply Chains: cost of item; volume of business; criticality of item; relationship level; years of association; risk/investment sharing; involved in product development; involved in product innovation and improvement; commitment to quality; commitment to delivery; contractual agreements; technical competency; experience in business; price negotiation; past track record; responsiveness to change; regularity of supplies; mutual dependency; knowledge transfer; end customer gets affected; complexity of specification; switching cost; power position; information sharing; supplier selection; and exclusivity of supplies.

The use of multiple criteria and the need to evaluate them increase the complexity of the Supplier Selection process significantly (Ho, Xu \& Dey, 2010; Agarwal et al., 2011; Viana \& Alencar, 2012; Lima Junior, Osiro \& Carpinetti, 2013; Guarnieri, 2015; Igoulalene, Benyoucef \& Tiwari, 2015; Karsak \& Dursun, 2015; Sultana, Ahmed \& Azeem, 2015; Yadav \& Sharma, 2015; Yadav \& Sharma, 2016; Çakir, 2017; Yildiz \& Yayla, 2017; Sarkar, Pratihar \& Sarkar, 2018). For that 
Chart 4 - List of criteria.

\begin{tabular}{|l|l|}
\hline \multicolumn{1}{|c|}{ Group } & \multicolumn{1}{c|}{ Criteria } \\
\hline $\begin{array}{l}\text { Structure and } \\
\text { Technological } \\
\text { Aspects }\end{array}$ & $\begin{array}{l}\text { Quality; Price; Delivery achievement; After sales service; Training } \\
\text { Support; Production capacity; Technology in use; Technical } \\
\text { knowledge; Geographical compatibility; Data exchange system; } \\
\text { Warranties policies; Firm size. }\end{array}$ \\
\hline $\begin{array}{l}\text { Commitment } \\
\text { and Strategic } \\
\text { Compatibility }\end{array}$ & $\begin{array}{l}\text { Partnership motivation; Strategy suitability; Top management } \\
\text { compatibility; Compatibility of operational levels and functions; } \\
\text { Willingness to share confidential information; Willingness to receive } \\
\text { visits; Willingness to long-term relationships; Willingness to resolve } \\
\text { conflicts; Feeling of trust; Communication. }\end{array}$ \\
\hline Management & $\begin{array}{l}\text { Economic performance; Financial stability; Process Operational } \\
\text { Controls; Investment Plan; Organizational structure; Interim staff } \\
\text { management; Security Management; Social responsibility; Fast } \\
\text { delivery time; Responsiveness to unexpected demands; Supplier } \\
\text { subcontracting; Responses to requests. }\end{array}$ \\
\hline Competences & $\begin{array}{l}\text { Manufacturing competence; Competence in the development of new } \\
\text { products and processes; Speed in innovation implementation; } \\
\text { Competence in reducing costs; Competence in improvement; } \\
\text { Competence as sales executive. }\end{array}$ \\
\hline Others & $\begin{array}{l}\text { Reputation in industry; Customer base; Awards and certificates; Legal } \\
\text { processes; History of past performances. }\end{array}$ \\
\hline
\end{tabular}

Source: Adapted from Furtado (2005).

reason special attention has been drawn to the implementation of methods that enable the combination of these criteria for evaluating suppliers. Therefore the Multicriteria Decision Aiding Approach was selected in order to create the proposed Model.

\subsection{Multicriteria Decision Aiding Approach}

The Multicriteria Decision Aiding Approach seeks to assist the solution of problems that demand a complex decision-making process by providing tools to Managers; that is, multicriteria decision-making problems (Almeida, 2011; Gomes \& Gomes, 2019).

The multicriteria decision-making problem consists of a situation where there are two alternatives to choose from. Such choice is made by the desire of achieving multiple goals, which are oftentimes conflicting themselves and related to variables that represent them and allow the evaluation of each alternative. Thus, these variables are called criteria (Almeida, 2013).

The type of solution targeted for a particular multicriteria decision-making problem, that is to say, the way the decision maker opts to compare the alternatives is called a problematic (Almeida, 2013), which can be classified as: 
- Choice problem (P. $\alpha$ ): it seeks to select a subset of alternatives;

- Classification problem (P. $\beta$ ): it seeks to assign each alternative to a class;

- Ranking problem (P. $\gamma$ ): it seeks to rank the alternatives;

- Description problem (P. $\delta$ ): it seeks to describe the alternatives and their consequences;

- Portfolio problem: it seeks to choose a subset of alternatives that meets the goals according to particular restrictions.

The Multicriteria Approach has a set of Methods developed to support and guide the decision makers when evaluating the alternatives according to a variety of criteria. The Multicriteria Methods are necessary when the objectives of a problem can not be represented by means of a single metric (Almeida, 2013; Gomes \& Gomes, 2019).

Ensslin, Montibeller Neto \& Noronha (2001) state that in the traditional Operational Research area Methods for evaluating the alternatives according to a single criterion, in which the best alternative is the one that optimizes a particular mathematical function, are used. In terms of the Multicriteria Approach, the alternatives are evaluated according to a set of criteria, in which each one is a function that measures the performance of the alternatives, aiming to optimize the functions simultaneously.

On one hand, Chai, Liu \& Ngai (2013) consider the Multicriteria Methods methodological frameworks whose goal is to provide the decision makers with recommendations based on a set of alternatives, actions, objects, solutions or candidates, which are evaluated from various viewpoints; that is, criteria, attributes, features or objectives. On the other hand, Almeida (2013) states that the Multicriteria Method consists of a methodological formulation or a theory with a well-defined axiomatic structure, which can be used in order to create a Model that seeks to resolve a specific problem. According to the author, the Multicriteria Method differs from the Multicriteria Model, because it is more general and can be applied to a broader class of decision-making problems.

The Multicriteria Methods can be classified in many different ways. The classifications mentioned by Almeida (2013) are synthesized in Chart 5.

As stated by Gomes \& Gomes (2019), the discrete Methods are suitable for resolving problems that have a finite number of alternatives. The continuous Methods, or Multicriteria or Interactive optimization, are suitable for resolving problems with an infinite number of alternatives. According to Almeida (2013), the majority of managerial problems have a discrete set of alternatives.

The Multicriteria Methods are classified as compensatory and noncompensatory due to the compensation that there can or can not be in the decision criteria (Almeida, 2013). In the former, a low performance of an alternative from a given criterion is compensated for by a better performance in another criterion, that is, trade-offs among criteria are considered. In the latter, there are no trade-offs, thus, the alternatives must have a satisfactory performance in most criteria. 
Chart 5 - Classification of the Multicriteria Methods.

\begin{tabular}{|l|l|}
\hline \multicolumn{1}{|c|}{ Classification } & \multicolumn{1}{c|}{ Typologies } \\
\hline $\begin{array}{l}\text { In terms of the nature of the set of } \\
\text { alternatives }\end{array}$ & $\begin{array}{l}\text { - Discrete set; } \\
\text { - Set of continuous alternatives. }\end{array}$ \\
\hline $\begin{array}{l}\text { In terms of the use of Methods of } \\
\text { mathematical programming }\end{array}$ & $\begin{array}{l}\text { - Linear programming; } \\
\text { - Nonlinear programming. }\end{array}$ \\
\hline $\begin{array}{l}\text { In terms of the structure of preference of } \\
\text { the decision maker and the type of } \\
\text { rationality he considers }\end{array}$ & $\begin{array}{l}\text { - Compensatory; } \\
\text { - Noncompensatory. }\end{array}$ \\
\hline $\begin{array}{l}\text { In terms of the approach or theory on } \\
\text { which it is based }\end{array}$ & $\begin{array}{l}\text {-Single Criterion Synthesis Methods; } \\
\text { - Outranking Methods; }\end{array}$ \\
\hline
\end{tabular}

Source: personal compilation (2020).

Chart 6 - Synthesis of the Multicriteria Approaches.

\begin{tabular}{|l|l|}
\hline \multicolumn{1}{|c|}{ Approach } & \multicolumn{1}{c|}{ Description } \\
\hline $\begin{array}{l}\text { Multiattribute Utility } \\
\text { or Single Criterion }\end{array}$ & $\begin{array}{l}\text { It is derived from the american current of thought, in which the } \\
\text { preferences of the decision maker for a particular alternative, } \\
\text { evaluated by means of a set of criteria, are aggregated with a } \\
\text { single utility value, which is measured in an additive manner } \\
\text { (with trade-offs). A score is generated for each alternative based } \\
\text { on the performance according to each criterion, thus, the best } \\
\text { evaluated alternatives are the ones that have the best score. }\end{array}$ \\
\hline Outranking & $\begin{array}{l}\text { It is derived from the french current of thought whose main } \\
\text { purpose is to create binary relations that represent the } \\
\text { preferences of the decision maker based on the available } \\
\text { information (without trade-offs). Therefore, through a pairwise } \\
\text { comparison the superior alternative in each criterion is verified, } \\
\text { creating an outranking relation from the confrontation between } \\
\text { two alternatives. Therefore, the alternative that shows } \\
\text { superiority in most criteria is best evaluated. This approach is } \\
\text { based on the Condorcet voting system. }\end{array}$ \\
\hline Interactive Methods & $\begin{array}{l}\text { They are developed in the Multi-objective Linear Programming } \\
\text { MOLP context. They have computational steps and are } \\
\text { interactive, that is, they allow trade-offs. They seek an } \\
\text { alternative that is overtly superior according to all objectives, } \\
\text { that is, a dominant one. Therefore, they aggregate the } \\
\text { preferences of the decision makers and mathematical, } \\
\text { interactive and successive calculations. }\end{array}$ \\
\hline
\end{tabular}

Source: Adapted from Guarnieri (2015)

Guarnieri (2015) emphasizes that the experts of the Multicriteria Approach divide the methods into three Approaches, which are presented and described in Chart 6. A fourth Approach is 
included by Gomes \& Gomes (2019), the one of Hybrid Methods, in which concepts of two or more Approaches are used.

The Outranking Approach Methods differ from those of the Single Criterion Synthesis Approach as they allow for a more flexible modeling of the problem, because they do not accept the comparability of all the alternatives and do not impose a hierarchical structure of the criteria (Gomes \& Gomes, 2019). However, as the Single Criterion Synthesis Methods achieve the analytical aggregation in order to achieve a score for each alternative, they facilitate the comparison of the alternatives (Almeida, 2013).

Ensslin, Montibeller Neto \& Noronha (2001) explain that both the Single Criterion Synthesis Approach and the Outranking Approach convey the idea of determining a general performance for each one of the alternatives. However, the latter determines the performance through the pairwise comparison of the performances of the alternatives for each criterion. Almeida (2013) concludes that the Outranking Methods show many characteristics that differ them from those of the Single Criterion Synthesis Methods. Nonetheless, the most important characteristic of the former is that it presents noncompensatory evaluations of the alternatives, whereas the latter presents compensatory evaluations.

Guarnieri (2015) states that Approach selection precedes the Method selection, which will greatly depend on the rationality of the decision maker once he shows his preferences (compensatory or noncompensatory). The author lists the main Methods for each one of the Approaches, as shown in Chart 7.

AHP is the most used Method and one of the first to be developed. It was created by Thomas Lorie Saaty in 1970 (Gomes \& Gomes, 2019). AHP and MAUT are considered the most representative Methods of the American School, whereas the ELECTRE Methods are the heart of the French School. The main Methods and their respective seminal references listed by Gomes, Costa \& Barros (2017) are presented in Chart 8.

There is no common ground in the adoption of the best Method. It is imperative to apply critical thinking, so that one's choice is adequate for the characteristics of the decision-making problem at hand (Gomes \& Gomes, 2019; Guarnieri, 2015).

According to Guarnieri (2015), in order to select the Method the following must be considered:

- The decision-making situation that encompasses the objectives;

- The problematic at hand (choice, ordination or classification);

- The types of criteria (quantitative and/or qualitative);

- The rationality of the decision maker (compensatory or noncompensatory). 
Chart 7 - Main Methods of the Multicriteria Decision Aiding Approach.

\begin{tabular}{|c|c|c|}
\hline Approach & Method & Description \\
\hline \multirow{4}{*}{ 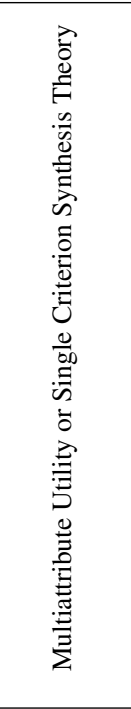 } & MAUT & $\begin{array}{l}\text { It is based on the modeling concepts of the traditional preference. It allows } \\
\text { trade-offs among criteria and two situations: strict preference and } \\
\text { indifference. An aggregate utility function is created, which aggregates the } \\
\text { criteria in a single criterion synthesis, showing the preferences of the } \\
\text { decision maker. It is an ordination Method. }\end{array}$ \\
\hline & SMART & $\begin{array}{l}\text { It is a simplified version of MAUT, which analyzes the evaluation of the } \\
\text { alternatives, taking into consideration the worst and the best stimulus. It } \\
\text { uses strategies of the heroic approach in order to justify the linear } \\
\text { approaches of the multidimensional utility functions. The aggregation of } \\
\text { the preferences of the decision maker based on the alternatives and the } \\
\text { criteria is additive, thus, it considers trade-offs. It is an ordination Method. }\end{array}$ \\
\hline & TOPSIS & $\begin{array}{l}\text { It evaluates the performance of the alternatives through the similarity to the } \\
\text { ideal solutions, in which the best alternative would be the one that is closest } \\
\text { to the positive ideal solution and farthest from the negative one. The } \\
\text { positive solution maximizes the benefit criteria and minimizes the cost } \\
\text { criteria, whereas the negative ideal solution maximizes the cost criteria and } \\
\text { minimizes the benefit criteria. It is an ordination Method that considers } \\
\text { trade-offs. }\end{array}$ \\
\hline & AHP & $\begin{array}{l}\text { It divides the problem into a variety of interrelated factors by means of the } \\
\text { creation of a hierarchy, which enables the decision maker to define the } \\
\text { priorities and judge the preferences according to the alternatives, comparing } \\
\text { them in pairs for each criterion through matrices and based on the Saaty's } \\
\text { numerical scale. It is an ordination Method that considers trade-offs. }\end{array}$ \\
\hline \multirow{2}{*}{ 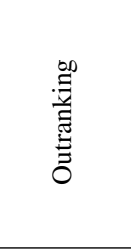 } & ELECTRE & $\begin{array}{l}\text { It is composed of two main procedures: creation of one or many outranking } \\
\text { relations, and the exploitation of these relations. The creation of one } \\
\text { outranking relation, or more, aims to compare each pair of alternatives. It } \\
\text { does not allow trade-offs. }\end{array}$ \\
\hline & PROMETHEE & $\begin{array}{l}\text { It consists of making a pairwise comparison of the alternatives and building } \\
\text { a relation of outranking values, which stands out because it involves } \\
\text { concepts and parameters that have a physical or economic interpretation. It } \\
\text { does not allow trade-offs. }\end{array}$ \\
\hline \multirow{4}{*}{ 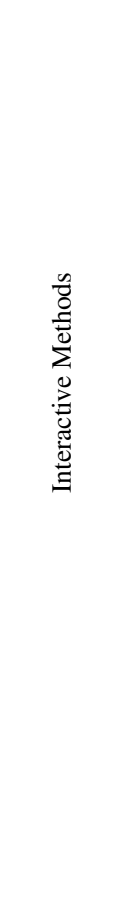 } & $\begin{array}{l}\text { Step Method - } \\
\text { STEM }\end{array}$ & $\begin{array}{l}\text { For each calculation phase, the solution that minimizes a Chebyshev heavy } \\
\text { distance to the ideal solution is sought, which is put to the appreciation of } \\
\text { the decision maker in the dialog phase. If all the values of the objective } \\
\text { functions are seen as satisfactory, the process comes to an end. Otherwise, } \\
\text { the decision maker establishes that the objective functions accept to relax } \\
\text { and the value of such a relaxation, so that the objectives that have not yet } \\
\text { attained satisfactory values are enhanced. It is a choice and an ordination } \\
\text { Method that considers trade-offs. }\end{array}$ \\
\hline & $\begin{array}{l}\text { Interval Criterion } \\
\text { Weights - ICW }\end{array}$ & $\begin{array}{l}\text { The decision maker chooses a solution according to a sample of } \\
\text { non-dominated solutions that is presented in each dialog phase. In each } \\
\text { calculation phase various weighted sums of the objective functions are } \\
\text { optimized through regularly dispersed combination weights in the } \\
\text { parametric diagram, which requires that the decision maker explicitly } \\
\text { indicates the weights. It is a choice Method that considers trade-offs. }\end{array}$ \\
\hline & Pareto Race & $\begin{array}{l}\text { It carries out a free directional research on the non-dominated region. The } \\
\text { information of the preferences consists of the indication of the objective } \\
\text { functions that need improving, which leads to the alteration of the research } \\
\text { direction. The solutions are calculated by establishing a direction that } \\
\text { provides a variation on the values of the objective functions in line with the } \\
\text { preferences of the decision maker, which is subsequently projected onto the } \\
\text { non-dominated region. It is a choice and an ordination Method that } \\
\text { considers trade-offs. }\end{array}$ \\
\hline & TRIMAP & $\begin{array}{l}\text { It conducts a free research in terms of a progressive and selective learning } \\
\text { of the set of non-dominated solutions, combining the reduction of the } \\
\text { admissible region with the reduction of the parametric diagram. In each } \\
\text { calculation phase a weighted sum of the objective functions is optimized. } \\
\text { The decision maker can specify inferior limitations for objective functions, } \\
\text { which are translated into the parametric diagram, and impose restrictions } \\
\text { directly on the weights. It is a choice and an ordination Method that } \\
\text { considers trade-offs. }\end{array}$ \\
\hline
\end{tabular}

Source: Adapted from Guarnieri (2015). 
Chart 8-Seminal references of the Multicriteria Methods.

\begin{tabular}{|l|l|}
\hline \multicolumn{1}{|c|}{ Method } & \multicolumn{1}{c|}{ Seminal References } \\
\hline BORDA & De Borda (1781) \\
\hline CONDORCET & Condorcet (1788) \\
\hline COPELAND & Copeland (1951) \\
\hline ELECTRE I & Roy (1968) \\
\hline ELECTRE II & Roy and Bertier (1971) \\
\hline ELECTRE III & Roy and Hugonnard (1981) \\
\hline ELECTRE IV & Roy and Hugonnard (1981) \\
\hline ELECTRE IS & Roy and M. (1985) \\
\hline ELECTRE TRI & Yu (1992) \\
\hline ELECTRE TRI-C & Almeida-Dias et al. (2010) \\
\hline ELECTRE TRI-n & Almeida-Dias et al. (2012) \\
\hline PROMETHEE & Brans et al. (1984), Brans et al. (1986) \\
\hline REGIME & Hinloopen et al. (1983) \\
\hline MAUT & Keeney and Raiffa (1976) \\
\hline SMART & Edwards (1977) \\
\hline AHP & Saaty (1977), Saaty (1980a) \\
\hline ANP & Saaty (1996) \\
\hline MACBETH & Bana, Costa and Vansnick (1994) \\
\hline TOMASO & Marichala et al. (2006) \\
\hline Verbal Decision & Larichev and Moshkovich (1997) \\
Analysis - VDA & Larichev and Moshkovich (1995) \\
\hline ZAPROS & Clímaco et al. (2009) \\
\hline VIP Analysis & Momes (2005), Gomes et al. (2008), Gomes, Gomes and \\
\hline THOR & Gomes and Lima (1992), Gomes, Gomes and Maranhão (2010) \\
\hline TODIM & Soran An \\
\hline
\end{tabular}

Source: Adapted from Gomes, Costa \& Barros (2017).

Almeida \& Costa (2003) emphasize other aspects such as:

- The problem that is being analyzed;

- The context and the available time for the process;

- The available information and the degree of precision;

- The structure of preferences of the decision maker in tandem with the required rationality.

According to Almeida (2013), selecting the Method is key to the process of creating the Multicriteria Models. Lima Júnior, Osiro \& Carpinetti (2013) explain that the resolution of the Model 
must obey a set of rules established by the selected Method, and such a choice must be made in the development phase of the Model.

As stated by Almeida (2013), the Multicriteria Model can use any one of the Methods, even if it is not totally adequate for the problem, in order to avoid the one that is more complex and difficult for the Model. Nevertheless, an evaluation based on the confrontation between the simplicity and the precision of the Model is always necessary. For the author, the simplification will lead to errors, however, the Model can still be useful.

\subsection{ELECTRE TRI Method}

In this research the ELECTRE TRI Method was selected to compose the Model that was created and validated, because it proposes to resolve the classification problem (P. $\beta$ ) (Mousseau \& Slowinski, 1998; Mousseau, Slowinski \& Zielniewicz, 2000; Mousseau, Figueira \& Naux, 2001; Almeida, 2013; Gomes \& Gomes, 2019; Guarnieri, 2015; Govindan \& Jepsen, 2016).

The selection of this Method also took into consideration the tendency found in the literature regarding the Supplier Selection subproblem in order to build collaborative relationships, in which the decision makers have shown a noncompensatory rationality; that is, without trade-off among the criteria, which is a characteristic of the Methods that compose the Outranking Approach (Guarnieri, 2012).

The ELECTRE Methods are implemented in two phases: i) creation of the outranking relation, which makes a pairwise comparison of the alternatives; and ii) exploitation of the outranking relation, in which a procedure or an algorithm is applied in order to resolve a problem according to the problematic at hand (Almeida, 2013).

These methods differ in terms of the type of problematic to be resolved, the intra-criteria and the inter-criteria information used, and the amount of outranking relations created and investigated (Gomes \& Gomes, 2019). The main ELECTRE Methods and their characteristics are shown in Chart 9.

Chart 9 - Main characteristics of the ELECTRE Methods.

\begin{tabular}{|c|c|c|c|c|}
\hline Methods & Type of problem & Type of criterion & Weights & Veto \\
\hline Electre I & Choice & True & Yes & Yes \\
\hline Electre IS & Choice & Pseudo & Yes & Yes \\
\hline Electre II & Ranking & True & Yes & Yes \\
\hline Electre III & Ranking & Pseudo & Yes & Yes \\
\hline Electre IV & Ranking & Pseudo & No & Yes \\
\hline Electre TRI & Classification & Pseudo & Yes & Yes \\
\hline
\end{tabular}

Source: Adapted from Gomes \& Gomes (2019).

The ELECTRE TRI Method was primarily defined by Yu (1992) and aims to assign the alternatives to predefined categories or classes, and the assignment of an alternative " $a$ " is the result of 
a comparison between that alternative and the reference alternatives, or profiles, that define the inferior and the superior limits of the classes (Mousseau \& Slowinski, 1998; Mousseau, Slowinski \& Zielniewicz, 2000; Mousseau, Figueira \& Naux, 2001; Almeida, 2013; Gomes \& Gomes, 2019; Guarnieri, 2015; Govindan \& Jepsen, 2016).

In ELECTRE TRI a set of evaluations of the alternatives is given for each criterion, that is, criteria indices $\left\{g_{1}, \ldots, g_{i}, \ldots g_{m}\right\}$ and a set of profile indices $\left\{b_{1}, \ldots, b_{h}, \ldots b_{p}\right\}$, classes $(p+1)$ are defined, in which $b_{h}$ represents the superior limit of the class $C_{h}$ and the inferior limit of the Class $C_{h+1}$, for $h=1,2, \ldots, p$ (Mousseau \& Slowinski, 1998; Mousseau, Slowinski \& Zielniewicz, 2000; Mousseau, Figueira \& Naux, 2001). Figure 4 illustrates the profiles according to the criteria, in which $b_{p+l}$ corresponds to the ideal alternative.

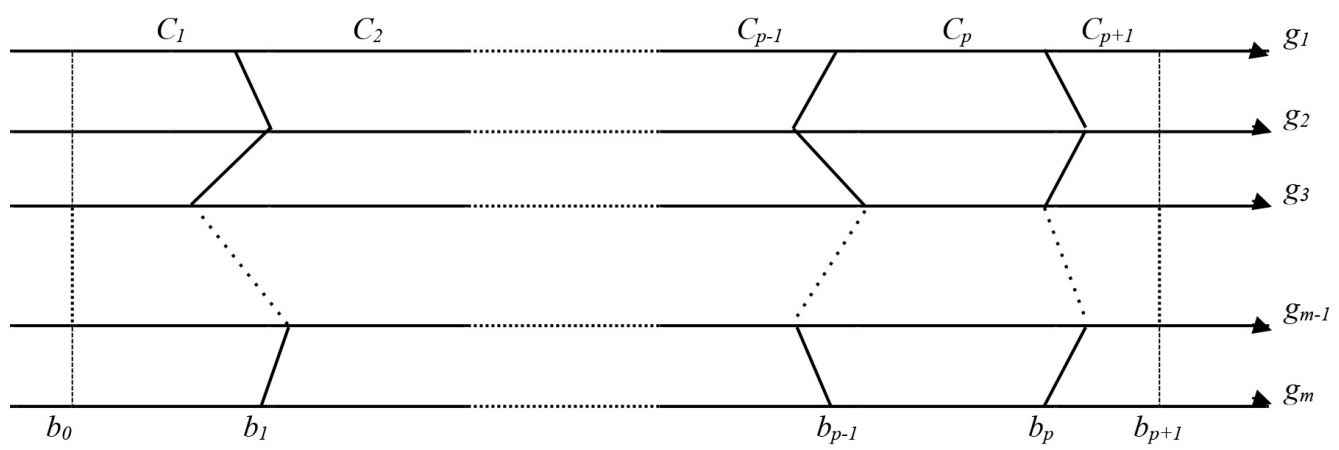

Figure 4 - Definition of the classes using limit profiles.

Source: Adapted from Mousseau, Slowinski \& Zielniewicz (2000).

The ELECTRE TRI Method assigns the alternatives to the classes after two steps: i) creation of the outranking relation $S$ to determine how the alternatives are compared to the limits of the classes; and ii) the exploitation of the relation $S$ in order to assign each alternative to a particular class (Mousseau, Slowinski \& Zielniewicz, 2000).

The outranking relation $S$ is created from the validation or invalidation of the assertion $a S b_{h}$ (ou $b_{h} S a$ ), whose meaning is "a is at least as good as $b_{h}$ " (Mousseau \& Slowinski, 1998; Mousseau, Slowinski \& Zielniewicz, 2000; Mousseau, Figueira \& Naux, 2001).

The preferences for each criterion are defined according to a pseudo-criteria, whose preference and indifference thresholds, $p_{j}\left[g\left(b_{h}\right)\right]$ e $q_{j}\left[g\left(b_{h}\right)\right]$, respectively, constitute the intra-criteria information. Therefore, $q_{j}\left[g\left(b_{h}\right)\right]$ specifies the largest difference $g_{j}(a)-g_{j}\left(b_{h}\right)$, which preserves the indifference between " $a$ " and $b_{h}$ on criterion $g_{j}$; and $p_{j}\left[g\left(b_{h}\right)\right]$ represents the smallest difference $g_{j}(a)-g_{j}\left(b_{h}\right)$, compatible with a preference of " $a$ " in relation to $b_{h}$ on criterion $g_{j}$ (Mousseau \& Slowinski, 1998; Mousseau, Slowinski \& Zielniewicz, 2000; Mousseau, Figueira \& Naux, 2001). In order to validate the assertion $a S b_{h}\left(\right.$ ou $b_{h} S a$ ), two conditions are verified (Mousseau \& Slowinski, 1998; Mousseau, Figueira \& Naux, 2001): 
- Concordance: for an outranking $a S b_{h}\left(o u b_{h} S a\right)$ to be accepted, a sufficient majority of criteria should be in favor of this assertion;

- Discordance: when the concordance condition is fulfilled, none of the criteria should oppose too strongly to the assertion $a S b_{h}\left(\right.$ ou $\left.b_{h} S a\right)$.

Two types of parameters interfere in the construction of the outranking relation (Mousseau \& Slowinski, 1998; Mousseau, Slowinski \& Zielniewicz, 2000; Mousseau, Figueira \& Naux, 2001):

- Set of weight coefficients $\left(w_{1}, w_{2}, \ldots, w_{m}\right)$, used in the concordance test;

- Set of veto thresholds $\left(v_{l}\left(b_{h}\right), v_{2}\left(b_{h}\right), \ldots, v_{m}\left(b_{h}\right.\right.$ used in the discordance test, in which $v_{j}\left(b_{h}\right)$ represents the smallest difference $g_{j}\left(b_{h}\right)-g_{j}(a)$, incompatible with the assertion $a S b_{h}$.

The Method computes an index $\sigma\left(a, b_{h}\right) \in[0,1]\left(\sigma\left(b_{h}, a\right)\right.$, respectively), which represents the degree of credibility of the assertion $a S b_{h}$ ( $b_{h} S a$, respectively), $\forall a \in A, \forall b_{h} \in B$. In order to define the credibility of the index, the partial concordance indices $c_{j}\left(a, b_{h}\right)$, the concordance indices $c\left(a, b_{h}\right)$ and the partial discordance indices $d_{j}\left(a, b_{h}\right)$. Accordingly, the following steps should be followed (Mousseau \& Slowinski, 1998; Mousseau, Slowinski \& Zielniewicz, 2000; Mousseau, Figueira \& Naux, 2001):

1. Compute the partial concordance indices $c_{j}\left(a, b_{h}\right) \forall_{j} \in F$ :

$$
c_{j}\left(a, b_{h}\right)=\left\{\begin{array}{l}
0, \text { if } g_{j}\left(b_{h}\right)-g_{j}(a) \geq p_{j}\left(b_{h}\right), \\
1, \text { if } g_{j}\left(b_{h}\right)-g_{j}(a) \leq q_{j}\left(b_{h}\right), \\
\frac{p_{j}\left(b_{h}\right)+g_{j}(a)-g_{j}\left(b_{h}\right)}{p_{j}\left(b_{h}\right)-q_{j}\left(b_{h}\right)}
\end{array}\right.
$$

2. Compute the concordance index $c\left(a, b_{h}\right)$ :

$$
c\left(a, b_{h}\right)=\frac{\sum j \in F w_{j} c_{j}\left(a, b_{h}\right)}{\sum j \in F w_{j}}
$$

3. Compute the partial discordance index $d_{j}\left(a, b_{h}\right) \forall_{j} \in F$ :

$$
d_{j}\left(a, b_{h}\right)=\left\{\begin{array}{l}
0, \text { if } g_{j}\left(b_{h}\right)-g_{j}(a) \leq p_{j}\left(b_{h}\right), \\
1, \text { if } g_{j}\left(b_{h}\right)-g_{j}(a)>v_{j}\left(b_{h}\right), \\
\frac{g_{j}\left(b_{h}\right)+g_{j}(a)-p_{j}\left(b_{h}\right)}{v_{j}\left(b_{h}\right)-p_{j}\left(b_{h}\right)}
\end{array}\right.
$$

4. Compute the credibility index $\sigma\left(a, b_{h}\right)$ of the outranking relation:

$$
\sigma\left(a, b_{h}\right)=c\left(a, b_{h}\right) . \prod j \in F \frac{1-d_{j}\left(a, b_{h}\right)}{1-c\left(a, b_{h}\right)} \text { where } F=\left\{j \in F: d_{j}\left(a, b_{h}\right)>c\left(a, b_{h}\right)\right\}
$$


It is necessary to implement an exploitation phase, since the assignment of the alternatives to the classes does not directly result from the outranking relation $S$. Thus, the assertion $a S b_{h}\left(b_{h} S a\right.$, respectively) is considered to be valid if $\sigma\left(a, b_{h}\right) \geq \lambda\left(\sigma\left(b_{h}, a\right) \geq \lambda\right.$, respectively), in which $\lambda$ is a cutting level such that $\lambda \in[0.5,1]$ (Mousseau \& Slowinski, 1998; Mousseau, Slowinski \& Zielniewicz, 2000; Mousseau, Figueira \& Naux, 2001).

The values of $\sigma\left(a, b_{h}\right), \sigma\left(b_{h}, a\right)$ and $\lambda$ indicate the preference situations between " $a$ " and " $b_{h}$ " through the following comparisons (Mousseau, Slowinski \& Zielniewicz, 2000; Mousseau, Figueira \& Naux, 2001):

- $\sigma\left(a, b_{h}\right) \geq \lambda$ e $\sigma\left(b_{h}, a\right) \geq \lambda$, which results in $a S b_{h}$ and $b_{h} S a$, being $a$ indifferent to $b_{h}$ $\left(a I b_{h}\right)$;

- $\sigma\left(a, b_{h}\right) \geq \lambda$ e $\sigma\left(b_{h}, a\right)<\lambda$, which results in $a S b_{h}$ and not $b_{h} S a$, being $a$ preferred to $b_{h}\left(a S b_{h}\right)$

- $\sigma\left(a, b_{h}\right)<\lambda$ e $\sigma\left(b_{h}, a\right) \geq \lambda$, which does not result in $a S b_{h}$ nor in $b_{h} S a$, being $b_{h}$ preferred to $a\left(b_{h} S a\right)$;

- $\sigma\left(a, b_{h}\right)<\lambda$ e $\sigma\left(b_{h}, a\right)<\lambda$, which does not result in $a S b_{h}$ nor in $b_{h} S a$, being $a$ incomparable to $b_{h}\left(a R b_{h}\right)$.

Finally, two assignment procedures are used; that is, two classification procedures of the alternatives whose role is to analyze how an alternative is compared to the profiles, so that the class to which that alternative should be assigned is defined (Mousseau \& Slowinski, 1998; Mousseau, Slowinski \& Zielniewicz, 2000; Mousseau, Figueira \& Naux, 2001):

- Pessimistic procedure: it compares " $a$ " successively to $b_{i}$, for $i=p, p-1, \ldots, 0$; being $b_{h}$ the first profile, such that $a S b_{h}, " a$ " must be assigned to class $C_{h+1}\left(a \rightarrow C_{h+1}\right)$;

- Optimistic procedure: it compares " $a$ " successively to $b_{i}$, for $i=1,2, \ldots, p+1$; being $b_{h}$ the first profile, such that " $b_{h}$ is preferred to $a$ " " $a$ " must be assigned to class $C_{h}\left(a \rightarrow C_{h}\right)$.

When the pessimistic procedure is used with $\lambda=1$, an alternative can only be assigned to the class $C_{h}$ if $g_{j}(a)$ is equal to or higher than $g_{j}\left(b_{h}\right)$ for each criterion. On the other hand, when the optimistic procedure is used with $\lambda=1$, an alternative can only be assigned to the class $C_{h}$ when $g_{j}\left(b_{h}\right)$ exceeds $g_{j}(a)$ for at least one criterion (Mousseau, Slowinski \& Zielniewicz, 2000; Mousseau, Figueira \& Naux, 2001).

In the pessimistic procedure the assignment of alternatives to the classes is achieved in a more conservative way. The alternatives are assigned to an inferior class other than the one determined by the profile; whereas in the optimistic procedure the less conservative, the higher the class that the alternatives are assigned to. On one hand, when there was a convergence between the two procedures, the system created to evaluate and rank the alternatives was capable of comparing 
them to the profiles. On the other hand, when there was a divergence, the system was not capable of doing the same (Costa, Santafé Júnior \& Haddad, 2007; Guarnieri, 2012).

Many papers issued in journals verify the suitability of the ELECTRE TRI Method for the classification problem (P. $\beta$ ), supporting the implementation of the Model that was built and validated in the present paper, such as: Dias \& Clímaco (2000); Dias et al. (2002); Miranda \& Almeida (2003); Costa, Soares \& Oliveira (2004); Lourenço \& Costa (2004); Szajubok, Alencar \& Almeida (2006); Szajubok, Mota \& Almeida (2006); Costa et al. (2007); Costa, Santafé Júnior \& Haddad (2007); Doumpos et al. (2009); Brito, Almeida \& Mota (2010); Cailloux, Meyer \& Mousseau (2012); Trojan \& Morais (2012); Fontana \& Cavalcante (2013); Costa et al. (2014); Freitas \& Silva (2014); Norese \& Carbone (2014); Sánchez-Lozano et al. (2014); Zheng et al. (2014); Corrente, Greco \& Slowinski (2016); Govindan \& Jepsen (2016); Lieggio Júnior et al. (2016); Sánchez-Lozano, García-Cascales \& Lamata (2016); Antonella et al. (2017); Aquino et al. (2017); Dias et al. (2018); Galo, Calache \& Carpinetti (2018); Ramezanian (2019).

\section{METHODOLOGY}

Applied, quantitative, exploratory and descriptive research methods were used. Twelve Managers who are responsible for the Supplier Selection in ten Brazilian Wind Energy companies participated in it. This research was divided into three steps, as shown in Figure 5.
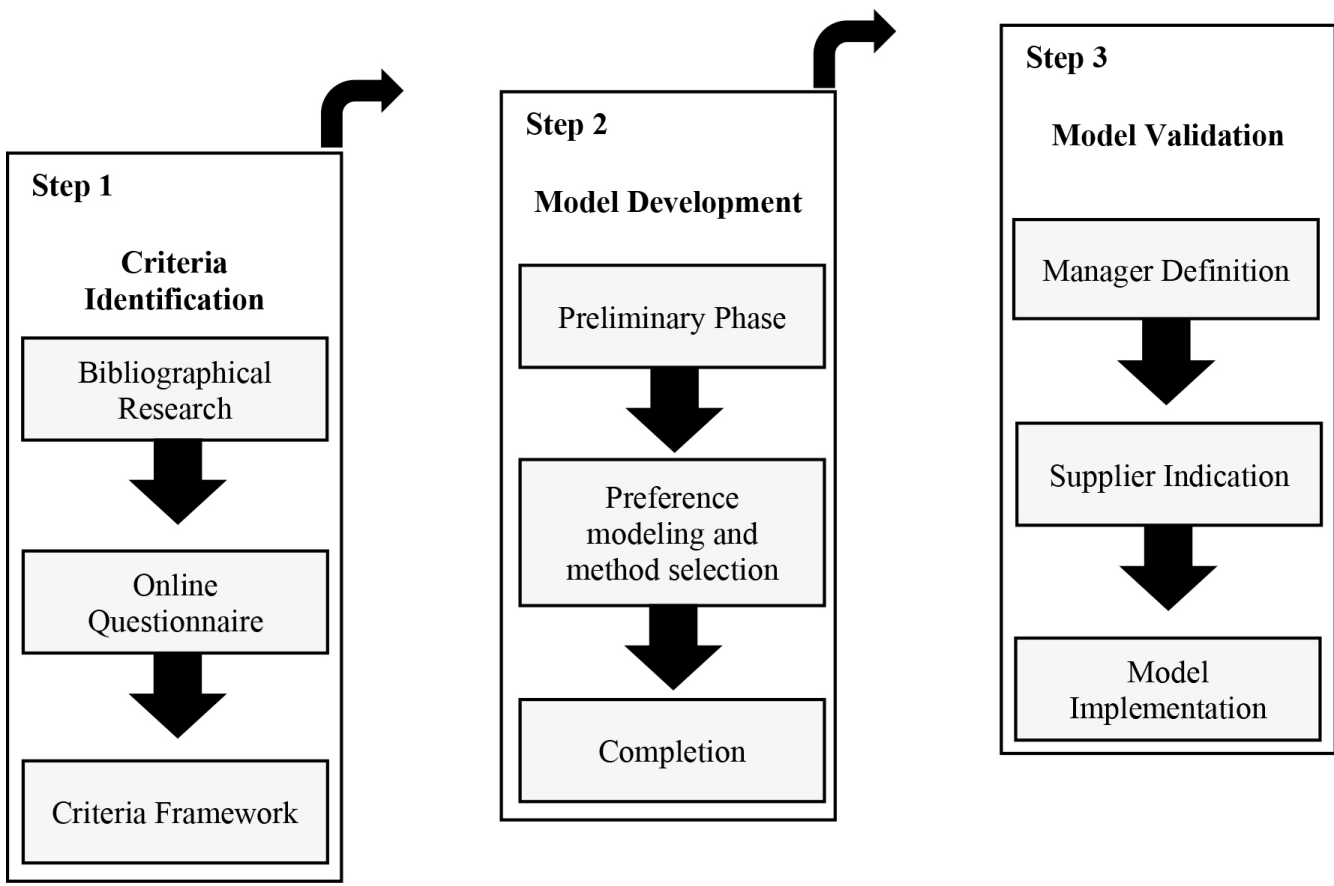

Figure 5 - Research Steps.

Source: personal compilation (2020). 
In step 1, an online questionnaire made available in April and May 2019 on SurveyMonkey® was used. It consisted of 04 questions whose purpose was to identify the currently used criteria for Supplier Selection, the criteria that could be included, currently used criteria from a list of 45 criteria validated by the literature, and the degree of importance given to each criterion in a Likert scale, varying from 1 - unimportant to 5 - very important.

Chart 10 shows the list of 45 criteria in which there are 30 general criteria of the Supplier Selection problem, and 15 specific criteria of the collaborative relationship subproblem, which are also called soft factors.

Chart 10 - Criteria List.

\begin{tabular}{|c|c|}
\hline \multicolumn{2}{|r|}{ Criteria } \\
\hline General & $\begin{array}{l}\text { Reciprocity arrangements; Production capacity; JIT capability; } \\
\text { Technical capability; Technology capacity; Compliance; Technical } \\
\text { knowledge; Economic performance; Delivery; Financial stability; } \\
\text { Organizational Structure; Experience; Flexibility; Management and } \\
\text { organization; Performance history; Innovation; Geographical location; } \\
\text { Research and Development; Warranties policies; Financial position; } \\
\text { Price; Quality; Reputation; Risks; Customer service; After sales } \\
\text { service; Support and training; Technology; Amount of business. }\end{array}$ \\
\hline Soft factors & $\begin{array}{l}\text { Joint actions; Establishment of common goals and objectives; Strategic } \\
\text { fit; Top management support; Information sharing; Commitment; } \\
\text { Communication; Trust; Cooperation; Compatible organizational } \\
\text { culture; Interdependence; Investment in Information Technology; Joint } \\
\text { planning; Decision synchronization; Transparency. }\end{array}$ \\
\hline
\end{tabular}

Source: personal compilation (2020).

These criteria were extracted from the bibliographical research about Supplier Selection discussed in Section 2.2. The criteria referenced by at least two authors were selected. The behaviors and the characteristics required on each relationship level in the Supply Chain according to Marqui, Moura \& Alcântara (2013) were also included.

In order to create a criteria framework, the most recurrent criteria in the open-ended questions ( 1 and 2), the referenced ones and the best evaluated ones in the close-ended questions ( 3 and 4 ) were taken into consideration. Thus, an amount of 15 criteria were selected in order to create the Model.

In Step 2 the Multicriteria Decision Aiding Model for Supplier Selection was created. For that purpose the procedure for resolving multicriteria decision-making problems proposed by Almeida (2013) was used, as shown in Figure 6.

In Step 3 the Model was validated, thus, one the Managers that participated in Step 1 was asked to evaluate the alternatives; that is, the suppliers of his firm. In terms of the Model validation, the ELECTRE TRI software was used, as ELECTRE TRI was the Multicriteria Method selected. 


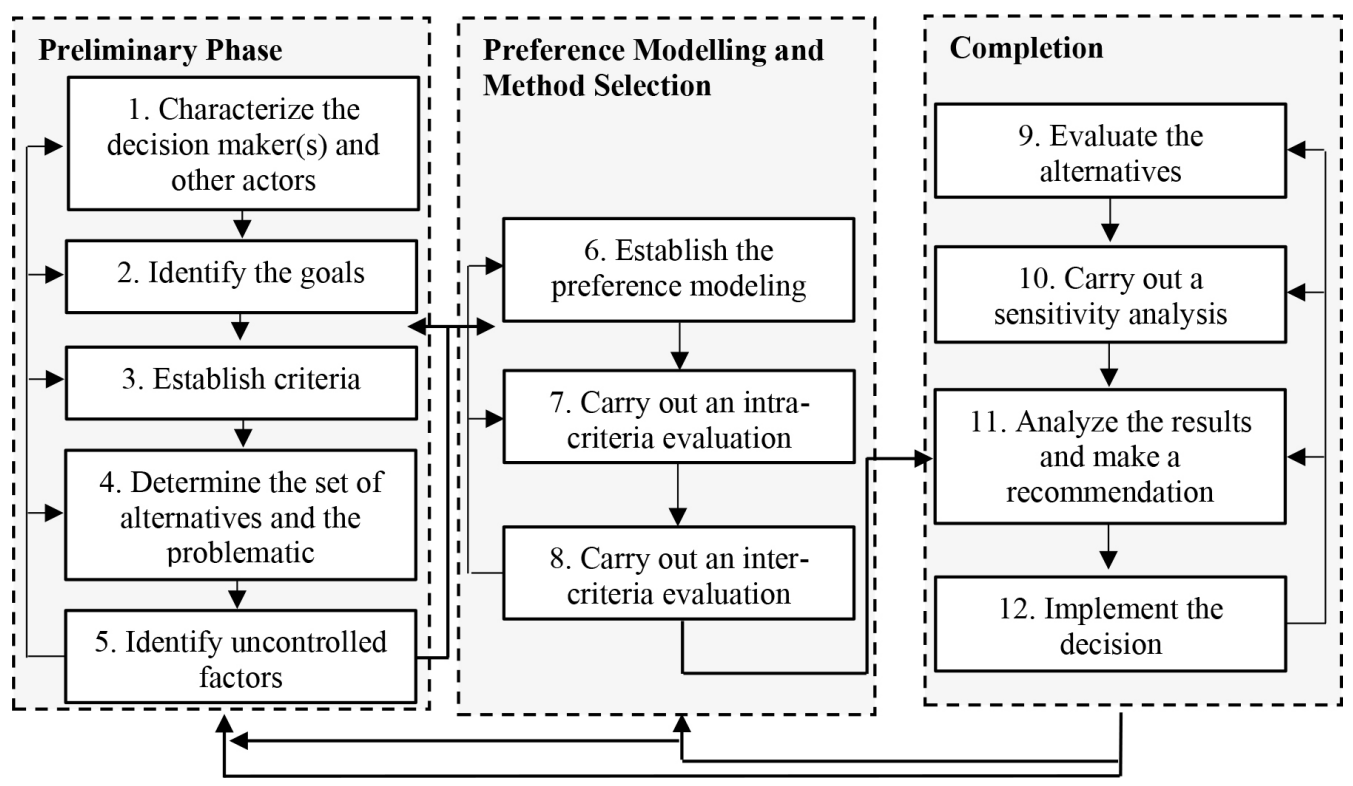

Figure 6 - Procedure for resolving decision-making problems.

Source: Adapted from Almeida (2013).

This software was developed at the Laboratoire d'Analyse et de Modélisation des Systèmes pour l'Aide à la Décision, at Paris Dauphine University, whose implementation followed the methodological guide and manual for users developed by Mousseau, Slowinski \& Zielniewicz (1999).

Once this Step was finished, the suppliers were classified according to their performance from a set of criteria on one of the three relationship levels of the Supply Chain. Subsequently the suppliers who meet the requirements that allow the creation of collaborative relationships in the Supply Chain of the Wind Energy Sector were identified.

\section{RESULTS}

\subsection{Criteria adopted by the firms}

After conducting the questionnaire, there was evidence that 07 criteria, which were not found among the 45 criteria validated by the literature, emerged from the open-ended questions. However, each one was mentioned by only one of the Managers; thus, it was not sufficient to include them in the framework. For that reason the criteria were selected based on the answers to the close-ended questions.

From the 45 criteria validated by the literature, the ones referenced by more than $50 \%$ of the Managers were chosen among price, technical capability, cost, experience, quality, financial stability, performance history, production capacity, technical knowledge, transparency, delivery, commit- 
ment and trust. In addition, from that same list of criteria the specific criteria of the collaborative relationship subproblem were extracted according to their degree of importance: information sharing, joint actions and interdependence. It is important to highlight that the price and the cost were merged together, because they have interrelated definitions.

Accordingly the criteria framework for Supplier Selection consisted of 15 criteria. There were 09 general criteria for the Supplier Selection problem, and 06 specific criteria for the collaborative relationship subproblem, also called soft factors, as shown in Chart 11. Therefore, the selection of the 15 criteria was a personal choice of the authors, who took into account the answers of the Managers that participated in the research.

The criteria that compose the framework were used in order to create and validate the Multicriteria Model subsequently.

\subsection{Model Development}

The Multicriteria Decision Aiding Model for Supplier Selection was created according to the standard procedure for resolving multicriteria decision-making problems proposed by Almeida (2013).

In step 1 the decision maker is described, his engagement is classified as being either direct or indirect, and the problem is identified, so that an individual or a joint decision is made. In this Model the problem consists of an individual decision, and the decision maker is the Manager responsible for the Selection of Suppliers of goods and services in the Wind Energy company.

In step 2 the strategic objectives are identified; the fundamental or end objectives that are essential to guide the effort when decision and evaluation of alternatives must be made; and the goal objectives that are useful for developing a Model in order to analyze decision-making problems and provide alternatives. Thus, the strategic objective aims to build collaborative relationships in the Supply Chain of the Wind Energy Sector. The end objective seeks to identify the suppliers who meet the requirements in order to create those kinds of relationships. The goal objective seeks to categorize the suppliers into the three relationship levels (cooperation, coordination and collaboration) according to his performance from the set of criteria.

In step 3 the criteria that represent the objectives shown in the previous step are established. For this Model 15 criteria were selected. There were 09 general criteria for the Supplier Selection problem, and 06 specific criteria for the collaborative relationship subproblem, also called soft factors, as shown in detail in Section 4.1.

The selected criteria meet the three necessary properties or requirements to adopt a coherent group of criteria proposed by Roy (1996), such as: nonredundancy, completeness and consistency. They also meet the properties proposed by Keeney (1992) and referenced by Almeida (2013), such as: measurability, operability and comprehensibility.

Some of the selected criteria that compose the Model are categorized as developed criteria, which are only adequate to a particular decision context and measured qualitatively (i.e.: joint actions 
Chart 11 - Criteria framework.

\begin{tabular}{|c|c|c|c|}
\hline \multicolumn{3}{|c|}{ Criteria } & Definition \\
\hline \multirow{9}{*}{ 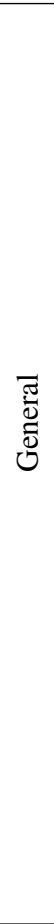 } & $\mathrm{C}_{1}$ & $\begin{array}{l}\text { Production } \\
\text { capacity }\end{array}$ & $\begin{array}{l}\text { Coherence between the quantity of products and services } \\
\text { required by the buyer and the quantity of products and services } \\
\text { produced by the supplier. }\end{array}$ \\
\hline & $\mathrm{C}_{2}$ & $\begin{array}{l}\text { Technical } \\
\text { capability }\end{array}$ & $\begin{array}{l}\text { Planning capacity and production scheduling in terms of } \\
\text { inspections and tests, equipment, maintenance plans and } \\
\text { workforce organization. }\end{array}$ \\
\hline & $\mathrm{C}_{3}$ & $\begin{array}{l}\text { Technical } \\
\text { knowledge }\end{array}$ & $\begin{array}{l}\text { Technical skill to meet the buyer's requirement of products and } \\
\text { services. }\end{array}$ \\
\hline & $\mathrm{C}_{4}$ & Delivery & $\begin{array}{l}\text { Keeping to the agreements reached in terms of deadlines, } \\
\text { quantity and transportation. }\end{array}$ \\
\hline & $\mathrm{C}_{5}$ & $\begin{array}{l}\text { Financial } \\
\text { stability }\end{array}$ & Current financial position of the buyer. \\
\hline & $\mathrm{C}_{6}$ & Experience & $\begin{array}{l}\text { Business experience and knowledge in understanding the } \\
\text { specification of the requirements of products and services. }\end{array}$ \\
\hline & $\mathrm{C}_{7}$ & $\begin{array}{l}\text { Performance } \\
\text { history }\end{array}$ & $\begin{array}{l}\text { Information about events, occurrences and past supply } \\
\text { performance. }\end{array}$ \\
\hline & $\mathrm{C}_{8}$ & Price/Cost & $\begin{array}{l}\text { Value of a good or a service according to the customer's } \\
\text { expectation, or consistent with the marketing environment of } \\
\text { the sector. }\end{array}$ \\
\hline & $\mathrm{C}_{9}$ & Quality & $\begin{array}{l}\text { Meeting of the specificities of products and services agreed by } \\
\text { the parties. }\end{array}$ \\
\hline \multirow{6}{*}{$\frac{\sum_{0}^{2}}{5}$} & $\mathrm{C}_{10}$ & Joint actions & $\begin{array}{l}\text { Joint commitment and engagement to resolve problems and } \\
\text { conflicts; development of activities and production, quality, } \\
\text { logistics, commercial and distribution processes; and } \\
\text { arrangement of meetings, technical visits and training. }\end{array}$ \\
\hline & $\mathrm{C}_{11}$ & $\begin{array}{l}\text { Information } \\
\text { sharing }\end{array}$ & $\begin{array}{l}\text { Willingness of the supplier to provide the necessary } \\
\text { information in order to assist the decision-making process. }\end{array}$ \\
\hline & $\mathrm{C}_{12}$ & Commitment & $\begin{array}{l}\text { Willingness to put in efforts and provide resources to support } \\
\text { the relationship and achieve the goals of the Supply Chain. }\end{array}$ \\
\hline & $\mathrm{C}_{13}$ & Trust & $\begin{array}{l}\text { Certainty that the partner is not to take advantage of the buying } \\
\text { firm, and that he will honor his commitments for the } \\
\text { relationship sake, including ethnic aspects and information } \\
\text { secrecy. }\end{array}$ \\
\hline & $\mathrm{C}_{14}$ & $\begin{array}{l}\text { Interdepen- } \\
\text { dence }\end{array}$ & $\begin{array}{l}\text { Dependence of a member regarding a particular knowledge } \\
\text { that a partner of the Supply Chain has, and vice versa. }\end{array}$ \\
\hline & $\mathrm{C}_{15}$ & Transparency & $\begin{array}{l}\text { Communication with the parties when any problem or possible } \\
\text { interruption in the Supply Chain activities is immediately } \\
\text { detected. }\end{array}$ \\
\hline
\end{tabular}

Source: Research Data (2020). 
and information sharing); hence, they require the development of qualitative evaluation scales, or subjective indices or scales. Others are classified as natural criteria, which can be used in various decision contexts and are measured quantitatively (i.e.: price, cost and delivery). However, in terms of collaborative relationships the interpretation of natural criteria is considered to have a qualitative connotation (Guarnieri, 2012).

Therefore, a verbal evaluation scale with Likert quantitative characteristics composed of five levels, varying from 1 - very low to 5 - very high, which is compatible with the human cognitive capacity to distinguish between different evaluation levels, was adopted for all the 15 criteria. It is a bipolar scale that measures the superior or inferior performance in terms of a value of central or intermediate position (Almeida, 2013).

Chart 12 exemplifies the evaluation scales developed for each one of the 15 criteria used in the Model.

Chart 12 - Evaluation scale for the quality criterion.

\begin{tabular}{|c|l|}
\hline Scale & C9 - Quality \\
\hline $\mathbf{1}$ & $\begin{array}{l}\text { The supplier shows a poor performance when it comes } \\
\text { to keeping to the agreements of the specificities of a } \\
\text { good or service. }\end{array}$ \\
\hline $\mathbf{2}$ & $\begin{array}{l}\text { The supplier shows an unsatisfactory performance when } \\
\text { it comes to keeping to the agreements of the specificities } \\
\text { of a good or service. }\end{array}$ \\
\hline $\mathbf{3}$ & $\begin{array}{l}\text { The supplier shows a moderately satisfactory } \\
\text { performance when it comes to keeping to the agreements } \\
\text { of the specificities of a good or service. }\end{array}$ \\
\hline $\mathbf{4}$ & $\begin{array}{l}\text { The supplier shows a satisfactory performance when it } \\
\text { comes to keeping to the agreements of the specificities } \\
\text { of a good or service. }\end{array}$ \\
\hline $\mathbf{5}$ & $\begin{array}{l}\text { The supplier shows a highly satisfactory performance } \\
\text { when it comes to keeping to the agreements of the } \\
\text { specificities of a good or service. }\end{array}$ \\
\hline
\end{tabular}

Source: personal compilation (2020).

In step 4 the structure of the set of actions is established (a discrete set or a set of continuous variables), the problem is identified (choice, classification or ranking), and the alternatives are provided. In this Model the set of actions corresponds to a discrete set, that is, a limited number of alternatives, which is described as $A=\left\{a_{1}, a_{2}, a_{3}, \ldots, a_{n}\right\}$, where the number of alternatives is equal to $n$. There is a classification problem (P. $\beta$ ), since the alternatives are expected to be assigned to the classes, that is, to one of the relationships of the Supply Chain.

The alternatives are the suppliers $S_{1}, S_{2}, S_{3}, \ldots, S_{n}$ of the Wind Energy companies who are evaluated according to their performance from the criteria $C_{1}, C_{2}, C_{3}, \ldots, C_{n}$, and subsequently 
categorized into one of the three classes. Figure 7 illustrates the classification structure of the alternatives of this Model.

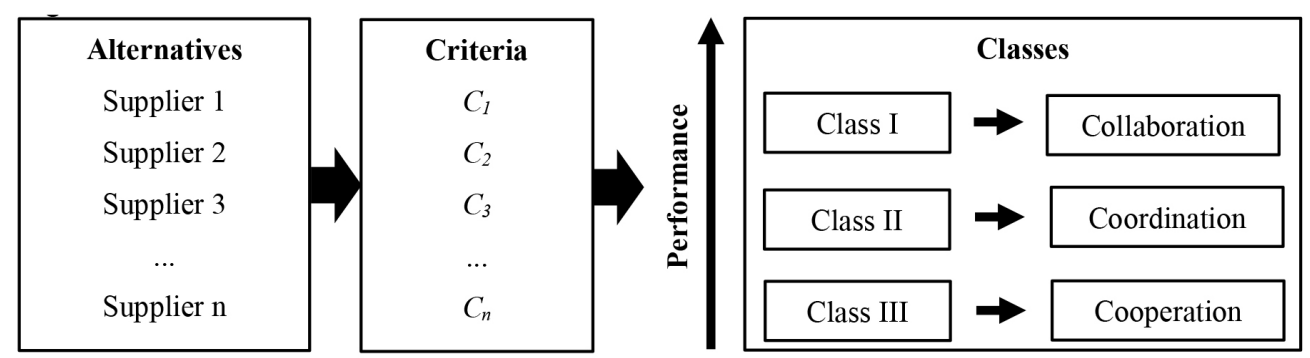

Figure 7 - Classification structure of the alternatives.

Source: personal compilation (2020).

In step 5 significant factors that are not in control of the decision makers are evaluated and identified, but it is not taken into consideration for this problem, because there are no variables in terms of state of nature that impact the consequence values, since all variables have a deterministic origin (Frej, 2017; Rodriguez, 2017).

In step 6 the most appropriate preference structure to indicate the preferences of the decision maker is evaluated; the most appropriate rationality for the decision maker regarding the problem at hand is established, which can involve the use of the compensatory or the noncompensatory approach; and finally, a preliminary selection of the Multicriteria Method was made. This step must be developed in tandem with steps 7 and 8 .

Because there is a classification problem (P. $\beta$ ), the ELECTRE TRI Method was selected to compose this Model, which aims to assign alternatives to predefined classes (Mousseau \& Slowinski, 1998; Mousseau, Slowinski \& Zielniewicz, 2000; Mousseau, Figueira \& Naux, 2001; Almeida, 2013; Gomes \& Gomes, 2019; Guarnieri, 2015; Govindan \& Jepsen, 2016).

In step 7 the intra-criteria evaluation was carried out, which depends on the type of Method to be adopted. Nonetheless, the results that affect the review of this choice made in the previous step can be obtained. In the Outranking Methods the evaluation of the indifference and the preference thresholds is considered (Almeida, 2013).

In the ELECTRE TRI Method the preferences for each criterion are defined according to a pseudo-criterion, where the preference $p_{j}\left[g\left(b_{h}\right)\right]$ and the indifference $q_{j}\left[g\left(b_{h}\right)\right]$ thresholds constitute the necessary information for the intra-criteria evaluation (Mousseau \& Slowinski, 1998; Mousseau, Slowinski \& Zielniewicz, 2000; Mousseau, Figueira \& Naux, 2001; Almeida, 2013):

- Preference threshold $p_{j}\left[g\left(b_{h}\right)\right]$ : it represents the smallest different $g_{j}(a)$ - $g j\left(b_{h}\right)$, compatible with the preference of " $a$ " in relation to $b_{h}$ on criterion $g_{j}$;

- Indifference threshold $q_{j}\left[g\left(b_{h}\right)\right]$ : it specifies the largest difference $g_{j}(a)$ - $g_{j}\left(b_{h}\right)$, which preserves the indifference between " $a$ " and $b_{h}$ on criterion $g_{j}$. 
The veto and the discordance thresholds, especially adopted in ELECTRE Methods, are also related to the intra-criteria preference of the decision maker. In the ELECTRE TRI Method a set of veto thresholds $\left(v_{1}\left(b_{h}\right), v_{2}\left(b_{h}\right), \ldots, v_{m}\left(b_{h}\right)\right)$ is used in the discordance test, in which $v_{j}\left(b_{h}\right)$ represents the smallest difference $g_{j}\left(b_{h}\right)-g_{j}(a)$, incompatible with the assertion $a S b_{h}$ (Mousseau \& Slowinski, 1998; Mousseau, Slowinski \& Zielniewicz, 2000; Mousseau, Figueira \& Naux, 2001; Almeida, 2013).

In situations where there is the classification problem (P. $\beta$ ), the description of the profiles to the classes is provided in this step, establishing the boundaries or limits between them (Almeida, 2013). As previously mentioned, the classes correspond to the three relationship levels of the Supply Chain: cooperation (Class III), coordination (Class II) and collaboration (Class I). The profiles that determine each one of these classes were defined according to the discussion presented in section 2.1, in which the limits were established taking into account the variation of the evaluation scale of the criteria (from 1 to 5).

The only restriction regarding the definition of these limits is that they must enable their comparison to the evaluation of the alternatives according to the criteria. Furthermore, it was evidenced that the best class (Class I) does not have a superior limit, and that the worst class (Class III) does not have an inferior limit (Costa, Santafé Júnior \& Haddad, 2007; Simões, 2013).

Even though there is a tendency in the literature to make an equidistant separation of the categories (Costa et al., 2007; Costa, Santafé Júnior \& Haddad, 2007; Guarnieri, 2012; Simões, 2013; Costa et al., 2014), this pattern was not followed. Chart 13 presents the classes and the profiles with the inferior and the superior limits.

Chart 13 - Classes and profiles of the Model.

\begin{tabular}{|c|c|l|c|c|}
\hline \multicolumn{2}{|c|}{ Classes } & \multicolumn{1}{c|}{ Description } & \multicolumn{2}{c|}{ Limits } \\
\cline { 4 - 5 } & Collaboration & $\begin{array}{l}\text { They meet the requirements that } \\
\text { allow the creation of collaborative } \\
\text { relationships }\end{array}$ & ---- & 4.0 \\
\hline II & Coordination & $\begin{array}{l}\text { They meet the requirements that } \\
\text { allow the creation of coordination } \\
\text { relationships }\end{array}$ & 4.0 & 3.0 \\
\hline III & Cooperation & $\begin{array}{l}\text { They meet the requirements that } \\
\text { allow the creation of cooperation } \\
\text { relationships }\end{array}$ & 3.0 & ----- \\
\hline
\end{tabular}

Source: personal compilation (2020).

The assignment of alternatives to the classes takes place after comparing their performances from the set of criteria according to what is established on the profiles. For that reason, an alternative is assigned to a particular class when, according to all the criteria, its evaluation is in between the 
inferior and the superior limits of this class (Mousseau \& Slowinski, 1998; Mousseau, Slowinski \& Zielniewicz, 2000; Mousseau, Figueira \& Naux, 2001; Costa, Santafé Júnior \& Haddad, 2007). Consequently, the suppliers who have the best performance according to all the criteria are sorted into Class I, because they meet the requirements that allow the creation of collaborative relationships in the Supply Chain. Whereas the suppliers who have an average or a weak performance are sorted into Classes II and III, for they still do not meet the requirements that allow the creation of collaborative relationships and need to make strategic changes, so that those relationships are built.

In step 8 the parameterization of the proposed Method is carried out, gathering the intra-criteria information from the decision maker, which enables the quantitative combination of the criteria in order to evaluate the alternatives. In the Outranking Approach Methods the inter-criteria evaluation can be represented by the weights of the criteria, which indicate the degree of importance (Almeida, 2013).

In this Model the weights of the criteria $\left(w_{1}, w_{2}, w_{3}, \ldots, w_{n}\right)$ must be determined by the decision maker. In order to indicate the relative importance of the criteria, direct rating as a weighing technique was used; accordingly, the decision maker should value each weight using the previously selected measurement scale, so that the values obtained are normalized (Gomes \& Gomes, 2019). Thus, the selected scale varies from 0 to 100 .

In step 9 the alternatives are evaluated broadly. Once the Model is consolidated, the selected Multicriteria Method is effectively implemented through the preferences of the decision maker according to the problem at hand.

In step 10 the sensitivity analysis is carried out, which consists of the study and analysis of the impact on the Model output caused by variations in the input; that is, the impact caused by the variations introduced in the input data, or in the Model parameters, were evaluated according to the results obtained from it (Almeida, 2013; Gomes \& Gomes, 2019). In this step one can conclude that the final result of step 9 is not appropriate; thus, it requires a review of the previous steps.

The procedure implemented in this step depends on the problem at hand. The classification problem (P. $\beta$ ) enables to evaluate to what extent the variations in the input data and in the parameters cause alterations that lead to, for example, the assignment of an alternative to a different class instead of the one that was initially determined by the Model (Almeida, 2013).

Almeida (2013) considers two types of procedures for the sensitivity analysis: a) isolated evaluation of parameters or of one type of input data, and b) joint evaluation of all parameters and input data, or a subset of those.

In step 11 after the two previous steps were concluded and there was no need to go back to the previous steps, the final analysis of the results is presented and the recommendations for the decision maker are made. In this step the decision maker is advised to what extent he can rely on the Model and the risks of the decision-making process are informed. 
Finally, in step 12 the action is carried out, or the procedures of the set of referenced actions are adopted, which is not applied in the present research. Figure 8 summarizes the proposed Multicriteria Decision Aiding Model.

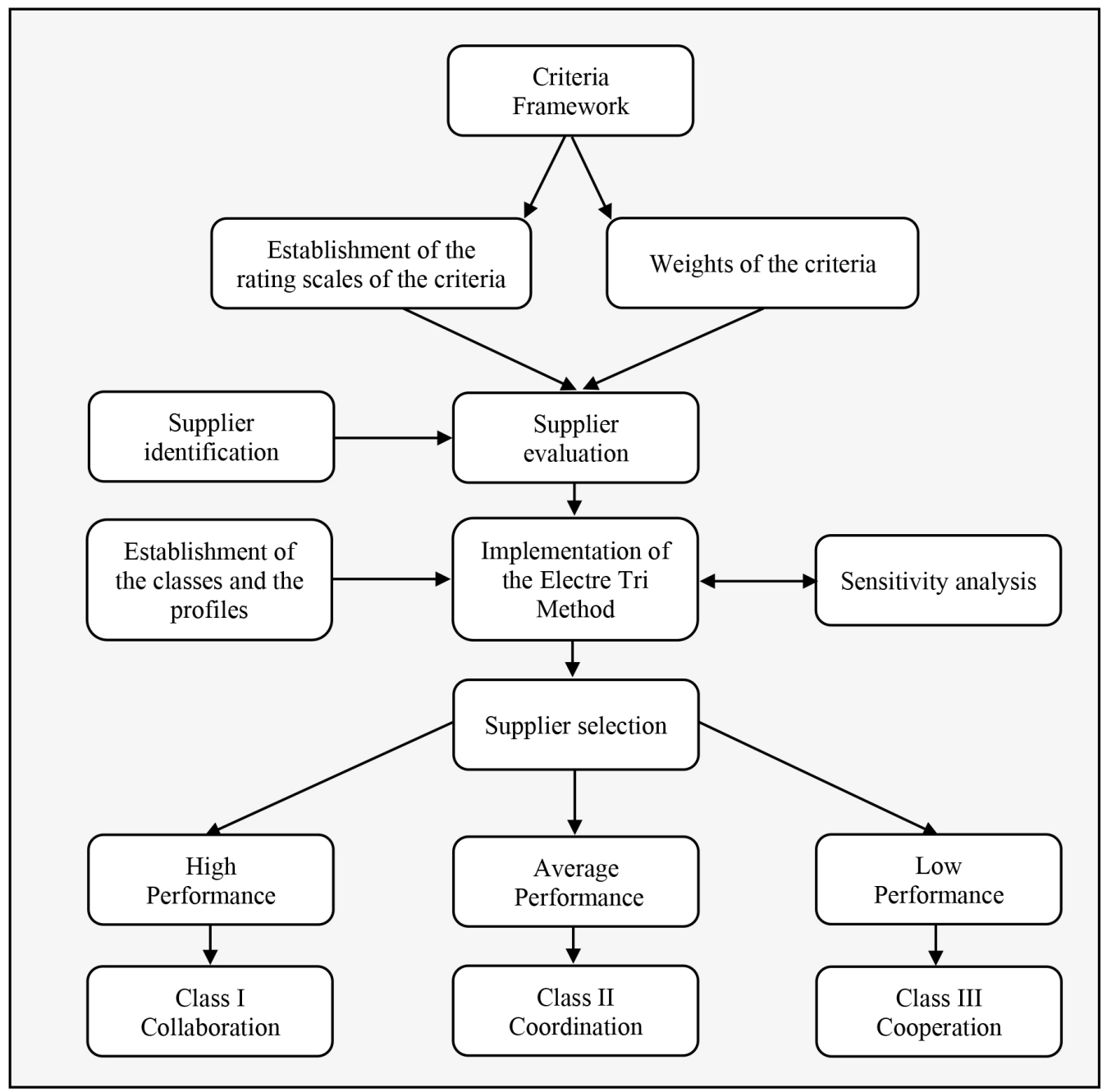

Figure 8 - The proposed Model.

Source: personal compilation (2020).

The proposed Models allows to categorize the suppliers into three relationship levels in a systematic and structured way according to their performance from a set of criteria in order to identify the ones that meet the requirements that allow the creation of collaborative relationships in the Supply Chain. Moreover, it aims to support Managers by minimizing decisions made solely based on their experiences, which can lead to risks and uncertainty. Furthermore, it aims to have 
them identify with greater reliability and ease the suppliers that meet the requirements that allow the creation of collaborative relationships in the Supply Chain.

It is paramount to emphasize that the Model is broad; therefore, not only is it suitable for the Wind Energy Sector, but it can also be adapted to other production sectors. In doing so, the selected criteria and the parameters should be changed.

\subsection{Model Validation}

Initially the Manager chose to evaluate the 10 main suppliers with whom his company keeps the highest amount of purchasing negotiations, as shown in Chart 14.

Chart 14 - Evaluated suppliers.

\begin{tabular}{|c|c|}
\hline \multicolumn{2}{|c|}{ Suppliers } \\
\hline$S_{1}$ & Wind turbines \\
\hline$S_{2}$ & Wind turbine blades \\
\hline$S_{3}$ & Subcomponents and supplies for wind turbines \\
\hline$S_{4}$ & Subcomponents and supplies for wind turbine blades \\
\hline$S_{5}$ & Subcomponents of the hub \\
\hline$S_{6}$ & Subcomponents of nacelle \\
\hline$S_{7}$ & Wind turbine assembly \\
\hline$S_{8}$ & Project development services \\
\hline$S_{9}$ & Preconstruction and construction services \\
\hline$S_{10}$ & O\&M services of wind farms \\
\hline
\end{tabular}

Source: Research Data (2020).

For the inter-criteria evaluation direct rating was the weighing method chosen. The Manager weighed the 15 criteria of the Model in a scale that varies from 0 to 100 . Table 1 shows the weights of the criteria.

Table 1 - Weights of the criteria.

\begin{tabular}{|c|c|c|c|c|c|c|c|c|c|c|c|c|c|c|c|}
\hline Criteria & $\mathbf{C}_{\mathbf{1}}$ & $\mathbf{C}_{\mathbf{2}}$ & $\mathbf{C}_{\mathbf{3}}$ & $\mathbf{C}_{\mathbf{4}}$ & $\mathbf{C}_{\mathbf{5}}$ & $\mathbf{C}_{\mathbf{6}}$ & $\mathbf{C}_{\mathbf{7}}$ & $\mathbf{C}_{\mathbf{8}}$ & $\mathbf{C}_{\mathbf{9}}$ & $\mathbf{C}_{\mathbf{1 0}}$ & $\mathbf{C}_{\mathbf{1 1}}$ & $\mathbf{C}_{\mathbf{1 2}}$ & $\mathbf{C}_{\mathbf{1 3}}$ & $\mathbf{C}_{\mathbf{1 4}}$ & $\mathbf{C}_{\mathbf{1 5}}$ \\
\hline Weights (w) & 50 & 100 & 90 & 70 & 60 & 70 & 70 & 90 & 90 & 40 & 50 & 80 & 60 & 40 & 90 \\
\hline
\end{tabular}

Source: Research Data (2020).

After that the weights were normalized by calculating their sum and dividing each one by the total sum. Table 2 shows the normalized weights.

Table 2 - Normalized weights.

\begin{tabular}{|c|c|c|c|c|c|c|c|c|c|c|c|c|c|c|c|}
\hline Criteria & $\mathbf{C}_{\mathbf{1}}$ & $\mathbf{C}_{\mathbf{2}}$ & $\mathbf{C}_{\mathbf{3}}$ & $\mathbf{C}_{\mathbf{4}}$ & $\mathbf{C}_{\mathbf{5}}$ & $\mathbf{C}_{\mathbf{6}}$ & $\mathbf{C}_{\mathbf{7}}$ & $\mathbf{C}_{\mathbf{8}}$ & $\mathbf{C}_{\mathbf{9}}$ & $\mathbf{C}_{\mathbf{1 0}}$ & $\mathbf{C}_{\mathbf{1 1}}$ & $\mathbf{C}_{\mathbf{1 2}}$ & $\mathbf{C}_{\mathbf{1 3}}$ & $\mathbf{C}_{\mathbf{1 4}}$ & $\mathbf{C}_{\mathbf{1 5}}$ \\
\hline Weights (w) & 0.05 & 0.10 & 0.09 & 0.07 & 0.06 & 0.07 & 0.07 & 0.09 & 0.09 & 0.04 & 0.05 & 0.08 & 0.06 & 0.04 & 0.09 \\
\hline
\end{tabular}

Source: Research Data (2020). 
For the intra-criteria evaluation the Manager evaluated the 10 suppliers according to the 15 criteria in a Likert scale, varying from 1 - very low to 5 - very high. Table 3 shows the consequence matrix, or decision matrix, which consists of the basic form of input data for most of the Multicriteria Methods. Each line of the matrix represents the consequence measures (or evaluations) of the alternative $i$ in relation to the criteria $m$; and each column expresses the consequence measures of the alternative $n$ in relation to the criteria $j$. An alternative $i$ for a criterion $j$, results in the value function $v_{j}\left(a_{i}\right)$, which is based on the evaluation of consequences to be obtained in each criterion (Almeida, 2013; Gomes \& Gomes, 2019).

Table 3 - Consequence matrix.

\begin{tabular}{|c|c|c|c|c|c|c|c|c|c|c|c|c|c|c|c|}
\hline \multirow{3}{*}{ Supplier } & \multicolumn{15}{|c|}{ Criteria } \\
\hline & \multicolumn{9}{|c|}{ General } & \multicolumn{6}{|c|}{ Soft factors } \\
\hline & $\mathrm{C}_{1}$ & $\mathrm{C}_{2}$ & $\mathbf{C}_{3}$ & $\mathrm{C}_{4}$ & $\mathrm{C}_{5}$ & $\mathrm{C}_{6}$ & $\mathrm{C}_{7}$ & $\mathrm{C}_{8}$ & $\mathrm{C}_{9}$ & $\mathrm{C}_{10}$ & $\mathrm{C}_{11}$ & $\mathrm{C}_{12}$ & $\mathbf{C}_{13}$ & $\mathrm{C}_{14}$ & $\mathrm{C}_{15}$ \\
\hline$S_{1}$ & 5 & 4 & 5 & 4 & 5 & 5 & 4 & 3 & 5 & 3 & 2 & 3 & 5 & 1 & 3 \\
\hline $\mathbf{S}_{2}$ & 5 & 4 & 5 & 4 & 5 & 5 & 4 & 3 & 5 & 3 & 2 & 3 & 5 & 1 & 3 \\
\hline $\mathbf{S}_{3}$ & 5 & 4 & 5 & 4 & 5 & 5 & 4 & 3 & 5 & 3 & 2 & 3 & 5 & 1 & 3 \\
\hline $\mathbf{S}_{4}$ & 5 & 4 & 5 & 4 & 5 & 5 & 4 & 3 & 5 & 3 & 2 & 3 & 5 & 1 & 3 \\
\hline $\mathbf{S}_{5}$ & 5 & 4 & 5 & 4 & 5 & 5 & 4 & 3 & 5 & 3 & 2 & 3 & 5 & 1 & 3 \\
\hline$S_{6}$ & 5 & 4 & 5 & 4 & 5 & 5 & 4 & 3 & 5 & 3 & 2 & 3 & 5 & 1 & 3 \\
\hline $\mathbf{S}_{7}$ & 5 & 5 & 5 & 5 & 5 & 5 & 5 & 2 & 5 & 4 & 5 & 5 & 5 & 3 & 4 \\
\hline $\mathbf{S}_{8}$ & 5 & 5 & 5 & 5 & 5 & 5 & 5 & 2 & 5 & 4 & 5 & 5 & 5 & 3 & 4 \\
\hline $\mathbf{S}_{9}$ & 4 & 3 & 3 & 4 & 4 & 5 & 4 & 2 & 4 & 4 & 5 & 5 & 5 & 3 & 4 \\
\hline$S_{10}$ & 5 & 5 & 5 & 5 & 5 & 5 & 5 & 3 & 5 & 4 & 4 & 5 & 5 & 4 & 5 \\
\hline
\end{tabular}

\subsubsection{Application of the ELECTRE TRI Method}

In the ELECTRE TRI application it is imperative to define the preference $p_{j}\left[g\left(b_{h}\right)\right]$ and the indifference $q_{j}\left[g\left(b_{h}\right)\right]$ thresholds for each criterion, which are the necessary information for the intra-criteria evaluation, enabling one to consider hesitation and uncertainty as related to human judgment (Mousseau \& Slowinski, 1998; Mousseau, Slowinski \& Zielniewicz, 2000; Mousseau, Figueira \& Naux, 2001; Costa, Santafé Júnior \& Haddad, 2007; Almeida, 2013).

However, in this application the preference $p_{j}\left[g\left(b_{h}\right)\right]$ and the indifference $q_{j}\left[g\left(b_{h}\right)\right]$ thresholds used were equal to zero for all criteria, because they do not apply to the type of evaluation scale used in the Model, which has full and discrete values and unitary values (Miranda \& Almeida, 2003; Szajubok, Alencar \& Almeida, 2006; Costa, Santafé Júnior \& Haddad, 2007).

Once the ELECTRE TRI Method is implemented, the veto or the discordance thresholds are also related to the intra-criteria preference of the decision maker (Almeida, 2013). Nonetheless, as in the works of Costa, Santafé Júnior \& Haddad (2007), Guarnieri (2012) and Calazans (2016), the veto thresholds $v_{j}\left(b_{h}\right)$ were not considered in this application, disabling them for all the criteria. 
The use of veto induces a tendency to categorize an alternative into a lower class. Mathematically speaking, to disable the concept of veto implies using a very large veto limit, avoiding the discordance effect and equalizing credibility to concordance (Costa, Santafé Júnior \& Haddad, 2007).

For the application of the ELECTRE TRI Method the software ELECTRE TRI 2.0a requires input data in order to calculate: the criteria list (name, code, weight and preference direction); the classes (name) and the profiles (name, code and limit); list of alternatives (name, code and performance in each of the criteria); preference $p_{j}\left(b_{h}\right)$, indifference $q_{j}\left(b_{h}\right)$ and veto $v_{j}\left(b_{h}\right)$ thresholds; and the cutting level $\lambda$.

An intermediate value of $\lambda=0.7$ was primarily chosen, considering that the cutting level $\lambda$ can vary from 0.5 to 1 , and that the higher, the more rigorous the assignment process of the alternatives.

The alternatives were assigned according to two assignment procedures: the pessimistic procedure, in which the assignment is carried out in a more conservative way, that is, the alternatives are assigned to an inferior class other than the one determined by the profile; and the optimistic procedure, which is less conservative and the alternatives are assigned to a superior class (Costa, Santafé Júnior \& Haddad, 2007; Guarnieri, 2012).

On one hand, when there were convergences between the two procedures, the system created to evaluate and classify the alternatives was capable of comparing them to the profiles of the classes. On the other hand, when there were divergences, the system was incapable to do so, which could be caused either by incoherence of the evaluator, and of the Model (including the set of criteria), or by the data collection system. The divergence of these classifications is common in situations where there are conflicting criteria, which is inherent to the problem; thus, it can not be seen as a modeling error (Costa et al., 2007; Costa, Santafé Júnior \& Haddad, 2007).

Chart 15 shows the assignments of the alternatives to the classes after comparing their performances from the set of criteria to what was established in the profiles.

According to Chart 15, for the cutting level $\lambda=0.7$ the assignments of the alternatives $S_{7}, S_{8}, S_{9}$ and $S_{10}$ converged in both assignment procedures, whereas the alternatives $S_{1}, S_{2}, S_{3}, S_{4}, S_{5}$ and $\mathrm{S}_{6}$ diverged. When there is a divergence, it is likely that the decision maker chooses the pessimist assignment procedure in case he is more strict; however, he is likely to choose the optimistic assignment procedure in case he is more flexible (Costa et al., 2007; Costa, Santafé Júnior \& Haddad, 2007).

Table 4 presents a statistical overview of the assignments; that is, the proportion of the alternatives assigned to each class for both assignment procedures.

Chart 16 shows the comparisons of the alternatives and the profiles of the classes that result in strict preference, weak preference, and indifference or incomparability relations (Mousseau, Slowinski \& Zielniewicz, 1999). 
Chart 15 - Assignment of the alternatives for $\lambda=0.7$.

\begin{tabular}{|c|c|c|}
\hline Alternatives & Pessimistic & Optimistic \\
\hline$S_{1}$ & Coordination & Collaboration \\
\hline$S_{2}$ & Coordination & Collaboration \\
\hline$S_{3}$ & Coordination & Collaboration \\
\hline$S_{4}$ & Coordination & Collaboration \\
\hline$S_{5}$ & Coordination & Collaboration \\
\hline$S_{6}$ & Coordination & Collaboration \\
\hline$S_{7}$ & Collaboration & Collaboration \\
\hline$S_{8}$ & Collaboration & Collaboration \\
\hline$S_{9}$ & Coordination & Coordination \\
\hline$S_{10}$ & Collaboration & Collaboration \\
\hline
\end{tabular}

Source: Research Data (2020).

Table 4 - Statistical overview of the assignments for a cutting level $\lambda=0.7$.

\begin{tabular}{|c|c|c|}
\hline Class & Pessimistic & Optimistic \\
\hline Collaboration & $30 \%(3$ out of 10$)$ & $90 \%(9$ out of 10$)$ \\
Coordination & $70 \%(7$ out of 10$)$ & $10 \%(1$ out of 10$)$ \\
Cooperation & $0 \%(0$ out of 10$)$ & $0 \%(0$ out of 10$)$ \\
\hline
\end{tabular}

Source: Research Data (2020).

Chart 16 - Comparison of each alternative to each profile $(\lambda=0.7)$.

\begin{tabular}{|c|c|c|}
\hline Alternatives & Class I Profiles & Class II Profiles \\
\hline $\mathrm{S}_{1}$ & Strict Preference & Incomparability \\
\hline $\mathrm{S}_{2}$ & Strict Preference & Incomparability \\
\hline $\mathrm{S}_{3}$ & Strict Preference & Incomparability \\
\hline $\mathrm{S}_{4}$ & Strict Preference & Incomparability \\
\hline $\mathrm{S}_{5}$ & Strict Preference & Incomparability \\
\hline $\mathrm{S}_{6}$ & Strict Preference & Incomparability \\
\hline $\mathrm{S}_{7}$ & Strict Preference & Strict Preference \\
\hline $\mathrm{S}_{8}$ & Strict Preference & Strict Preference \\
\hline $\mathrm{S}_{9}$ & Strict Preference & Weak Preference \\
\hline $\mathrm{S}_{10}$ & Strict Preference & Strict Preference \\
\hline
\end{tabular}

In Chart 16 there are 06 alternatives that present incomparabilities when compared to the profile of Class II; thus, it shows that the decision maker is not able to make all the comparisons, or that he does not wish to make them (Almeida, 2013). The occurrence of incomparabilities indicates 
that there are inconsistencies regarding the creation of the Model, thus, the parameters must be revised (Costa et al., 2007; Guarnieri, 2012).

\subsubsection{Sensitivity Analysis}

In the sensitivity analysis the isolated evaluation of parameters was used, that is, of a single type of input data, the cutting level $\lambda$, since the preference $p_{j}\left(b_{h}\right)$ and the indifference $q_{j}\left(b_{h}\right)$ thresholds equal to zero were established for this Model, and the veto thresholds $v_{j}\left(b_{h}\right)$ were disabled.

Chart 17 shows the assignment of the alternatives to the classes for $\lambda=0.6$.

Chart 17 - Assignment of the alternatives for $\lambda=0.6$.

\begin{tabular}{|c|c|c|}
\hline Alternatives & Pessimistic & Optimistic \\
\hline$S_{1}$ & Collaboration & Collaboration \\
\hline$S_{2}$ & Collaboration & Collaboration \\
\hline$S_{3}$ & Collaboration & Collaboration \\
\hline$S_{4}$ & Collaboration & Collaboration \\
\hline$S_{5}$ & Collaboration & Collaboration \\
\hline$S_{6}$ & Collaboration & Collaboration \\
\hline$S_{7}$ & Collaboration & Collaboration \\
\hline$S_{8}$ & Collaboration & Collaboration \\
\hline$S_{9}$ & Collaboration & Collaboration \\
\hline$S_{10}$ & Collaboration & Collaboration \\
\hline
\end{tabular}

Source: Research Data (2020).

As shown in Chart 17, for the cutting level $\lambda=0.6$ the assignments of all alternatives converged in the two assignment procedures. Table 5 presents a statistical overview of the assignments of alternatives.

Table 5 - Statistical overview of assignments for a cutting level $\lambda=0.6$.

\begin{tabular}{|c|c|c|}
\hline Class & Pessimistic & Optimistic \\
\hline Collaboration & $100 \%(10$ out of 10$)$ & $100 \%(10$ out of 10$)$ \\
Coordination & $0 \%(0$ out of 10$)$ & $0 \%(0$ out of 10$)$ \\
Cooperation & $0 \%(0$ out of 10$)$ & $0 \%(0$ out of 10$)$ \\
\hline
\end{tabular}

Source: Research Data (2020).

Chart 18 shows the comparisons of the alternatives and the profiles of the classes.

As shown in Chart 18, the alternatives do not present incomparabilities when compared to the profiles of the classes, because the value of the cutting level is smaller and less rigorous than the previous one $(\lambda=0.7)$ (Guarnieri, 2012).

Chart 19 shows the assignment of the alternatives to the classes for $\lambda=0.8$. 
Chart 18 - Comparison of each alternative to each profile $(\lambda=0.6)$.

\begin{tabular}{|c|c|c|}
\hline Alternatives & Class I Profiles & Class II Profiles \\
\hline$S_{1}$ & Strict Preference & Indifference \\
\hline$S_{2}$ & Strict Preference & Indifference \\
\hline$S_{3}$ & Strict Preference & Indifference \\
\hline$S_{4}$ & Strict Preference & Indifference \\
\hline$S_{5}$ & Strict Preference & Indifference \\
\hline$S_{6}$ & Strict Preference & Indifference \\
\hline$S_{7}$ & Strict Preference & Strict Preference \\
\hline$S_{8}$ & Strict Preference & Strict Preference \\
\hline$S_{9}$ & Strict Preference & Indifference \\
\hline$S_{10}$ & Strict Preference & Strict Preference \\
\hline \multicolumn{3}{|c}{ Source: Research Data (2020). }
\end{tabular}

Chart 19 - Assignment of the alternatives for $\lambda=0.8$.

\begin{tabular}{|c|c|c|}
\hline Alternatives & Pessimistic & Optimistic \\
\hline$S_{1}$ & Coordination & Collaboration \\
\hline$S_{2}$ & Coordination & Collaboration \\
\hline$S_{3}$ & Coordination & Collaboration \\
\hline$S_{4}$ & Coordination & Collaboration \\
\hline$S_{5}$ & Coordination & Collaboration \\
\hline$S_{6}$ & Coordination & Collaboration \\
\hline$S_{7}$ & Collaboration & Collaboration \\
\hline$S_{8}$ & Collaboration & Collaboration \\
\hline$S_{9}$ & Coordination & Collaboration \\
\hline$S_{10}$ & Collaboration & Collaboration \\
\hline
\end{tabular}

Source: Research Data (2020).

As shown in Chart 19, for the cutting level $\lambda=0.8$, the assignment of the alternatives $S_{7}, S_{8}$ and $S_{10}$ converged in the two assignment procedures; whereas the alternatives $S_{1}, S_{2}, S_{3}, S_{4}, S_{5}$, $S_{6}$ and $S_{9}$ diverged. Therefore, one verifies that the assignment of alternatives for this cutting level shows a higher divergence, which indicates the incapacity of the system to compare the alternatives to the profiles in higher cutting levels.

Table 6 presents a statistical overview of the assignments of alternatives.

Chart 20 shows the comparisons of the alternatives and the profiles of the classes.

As shown in Chart 20,07 alternatives present incomparabilities when compared to the profile of Class II; thus, it shows that the decision maker is not able to make all the comparisons, or that he does not wish to make them (Almeida, 2013). 
Table 6 - Statistical overview of the assignments for a cutting level $\lambda=0.8$.

\begin{tabular}{|c|c|c|}
\hline Class & Pessimistic & Optimistic \\
\hline Collaboration & $30 \%(3$ out of 10$)$ & $100 \%(10$ out of 10$)$ \\
Coordination & $70 \%(7$ out of 10$)$ & $0 \%(0$ out of 10$)$ \\
Cooperation & $0 \%(0$ out of 10$)$ & $0 \%(0$ out of 10$)$ \\
\hline
\end{tabular}

Source: Research Data (2020).

Chart 20 - Comparisons of each alternative to each profile $(\lambda=0.8)$.

\begin{tabular}{|c|c|c|}
\hline Alternatives & Class I Profiles & Class II Profiles \\
\hline $\mathrm{S}_{1}$ & Strict Preference & Incomparability \\
\hline $\mathrm{S}_{2}$ & Strict Preference & Incomparability \\
\hline $\mathrm{S}_{3}$ & Strict Preference & Incomparability \\
\hline $\mathrm{S}_{4}$ & Strict Preference & Incomparability \\
\hline $\mathrm{S}_{5}$ & Strict Preference & Incomparability \\
\hline $\mathrm{S}_{6}$ & Strict Preference & Incomparability \\
\hline $\mathrm{S}_{7}$ & Strict Preference & Strict Preference \\
\hline $\mathrm{S}_{8}$ & Strict Preference & Strict Preference \\
\hline $\mathrm{S}_{9}$ & Strict Preference & Incomparability \\
\hline $\mathrm{S}_{10}$ & Strict Preference & Strict Preference \\
\hline
\end{tabular}

Source: Research Data (2020).

Chart 21 compares the assignments of the alternatives for the three cutting levels.

Chart 21 - Comparison of the assignments for different cutting levels.

\begin{tabular}{|c|c|c|c|c|}
\hline Classes & $\begin{array}{l}\text { Assignment } \\
\text { procedures }\end{array}$ & $\lambda=0.6$ & $\lambda=0.7$ & $\lambda=0.8$ \\
\hline \multirow[t]{2}{*}{ Collaboration } & Pessimistic & $\begin{array}{l}S_{1}, S_{2}, S_{3}, S_{4}, S_{5}, \\
S_{6}, S_{7}, S_{8}, S_{9} \text { and } \\
S_{10}\end{array}$ & $\mathrm{~S}_{7}, \mathrm{~S}_{8}$ and $\mathrm{S}_{10}$ & $\mathrm{~S}_{7}, \mathrm{~S}_{8}$ and $\mathrm{S}_{10}$ \\
\hline & Optimistic & $\begin{array}{l}\mathrm{S}_{1}, \mathrm{~S}_{2}, \mathrm{~S}_{3}, \mathrm{~S}_{4}, \mathrm{~S}_{5}, \\
\mathrm{~S}_{6}, \mathrm{~S}_{7}, \mathrm{~S}_{8}, \mathrm{~S}_{9} \text { and } \\
\mathrm{S}_{10}\end{array}$ & $\begin{array}{l}\mathrm{S}_{1}, \mathrm{~S}_{2}, \mathrm{~S}_{3}, \mathrm{~S}_{4}, \mathrm{~S}_{5}, \\
\mathrm{~S}_{6}, \mathrm{~S}_{7}, \mathrm{~S}_{8} \text { and } \\
\mathrm{S}_{10}\end{array}$ & $\begin{array}{l}\mathrm{S}_{1}, \mathrm{~S}_{2}, \mathrm{~S}_{3}, \mathrm{~S}_{4}, \mathrm{~S}_{5}, \\
\mathrm{~S}_{6}, \mathrm{~S}_{7}, \mathrm{~S}_{8}, \mathrm{~S}_{9} \text { and } \\
\mathrm{S}_{10}\end{array}$ \\
\hline \multirow[t]{2}{*}{ Coordination } & Pessimistic & ---- & $\begin{array}{l}\mathrm{S}_{1}, \mathrm{~S}_{2}, \mathrm{~S}_{3}, \mathrm{~S}_{4}, \mathrm{~S}_{5}, \\
\mathrm{~S}_{6} \text { and } \mathrm{S}_{9}\end{array}$ & $\begin{array}{l}\mathrm{S}_{1}, \mathrm{~S}_{2}, \mathrm{~S}_{3}, \mathrm{~S}_{4}, \mathrm{~S}_{5}, \\
\mathrm{~S}_{6} \text { and } \mathrm{S}_{9}\end{array}$ \\
\hline & Optimistic & ---- & $\mathrm{S}_{9}$ & ---- \\
\hline \multirow{2}{*}{ Cooperation } & Pessimistic & ---- & ---- & ---- \\
\hline & Optimistic & ---- & ---- & ---- \\
\hline
\end{tabular}

Source: Research Data (2020). 
The alternatives were not assigned to Class III - Cooperation for any cutting level, which can be explained by the decision of the Manager in assessing only the 10 main suppliers with whom his firm keeps the highest volume of purchasing negotiations.

It is observed that the assignments of all alternatives converged in the two assignment procedures only for the cutting level $\lambda=0.6$. Guarnieri (2012) states that the lowest cutting levels offer more convergent assignments; however, they also reduce the level of credibility of the Model in providing more rigorous solutions. In contrast, higher levels increase the reliability of the Model and enable more accurate decisions to be made.

It is worth saying that in the sensitivity analysis other input data, or parameters, could be altered in order to evaluate the impact of the Model, such as the preference, the indifference and the veto thresholds, and the weights of the criteria.

\subsubsection{Final analysis of the results and recommendations for the decision maker}

The best results were obtained for the cutting level $\lambda=0.6$, in which not only did the assignments of all alternatives converge in both assignment procedures, but also that there were no incomparabilities. Thus, at this level the 10 evaluated suppliers showed a high performance in the set of criteria and were classified in Class I - Collaboration. That is, they meet the requirements that allow the creation of collaborative relationships in the Supply Chain in the Wind Energy Sector.

For that reason it is feasible to adopt collaborative strategies through partnerships and long-term contracts between the Wind Energy company and these 10 suppliers, which tend to contribute significantly to the minimization of disharmony in the supply of goods and services, the reduction of costs, the increase in competitivity and the warranty of supply, as well as other advantages.

The result obtained in this application does not seek to provide the decision maker with the solution to his problem, or establish a single truth, but to support the decision-making process by recommending actions or courses of actions.

\section{CONCLUSION}

The present paper proposed a Supplier Selection Model in order to build collaborative relationships in the Supply Chain, so that the Suppliers are previously categorized into the cooperation, coordination and collaboration levels. The ELECTRE TRI Method was used as a tool to achieve the main goal of the research.

The proposed Model aims to aid the decision-making process of managers whose firms are involved in the Supply Chains, and not only the ones from the Wind Energy Sector. Thus, that allows them to identify with greater reliability and ease the suppliers who meet the requirements that allow the creation of collaborative relationships.

Firms can use the Model periodically in order to revise the supplier assessment and, if needed, direct them to either an inferior or superior class. For example, a supplier who has been primarily 
categorized into the collaboration level (Class I) can, due to a new evaluation, show a poor performance according to the set of criteria; hence, he can be reassigned to an inferior class, either to coordination (Class II) or to cooperation (Class III).

The increase in the quantity of firms and Managers is recommended, so that there can be a more reliable identification of the criteria selected for the Supplier Selection, and that the proposed Model is implemented in other productive sectors where there is an incentive to the adoption of strategies for Collaborative Supply Chains.

Moreover, it is recommended the use of other softwares for future applications of the ELECTRE TRI Methods, such as the J-ELECTRE-v2.0. The latter is an executable .jar file that does not need to be installed and can be executed in any operating system, as it only requires a recent JAVA SE program. This software was developed by Pereira, Costa and Nepomuceno (2019), Professors at the Federal University of Fluminense - UFF, and it is available on the following website: https://sourceforge.net/projects/j-electre/files/.

In conclusion, it is also recommended that in order to compare the results other suitable Multicriteria Methods to resolve the classification problem are selected, such as PROMSORT, which is derived from PROMETHEE. As ELECTRE TRI, the latter belongs to the Outranking Approach or the French School in Multicriteria Decision Aid. In addition, it is suggested the use of the Fuzzy Logic, which is commonly integrated to the Multi-criteria Methods due to its capacity to easily capture the subjective evaluations of the decision makers; thus, it models the subjective processes of human evaluation, converting the evaluation scales into Fuzzy numbers.

\section{References}

[1] Agência Brasileira de Desenvolvimento Industrial - ABDi. 2014. Mapeamento da Cadeia Produtiva da Indústria Eólica no Brasil. Ministério do Desenvolvimento, Indústria e Comércio Exterior - MDIC, Brasília, DF, Brasil.

[2] Agarwal P, Sahai M, Mishra V, Bag M \& Singh V. 2011. A review of multicriteria decision making techniques for supplier evaluation and selection. International Journal of Industrial Engineering Computations, 2(4): 801-810.

[3] Almeida AT. 2011. O conhecimento e o uso de métodos multicritério de apoio a decisão. $2^{\text {nd }}$ ed. Recife: Editora Universitária da UFPE.

[4] Almeida AT. 2013. Processo de Decisão nas organizações: construindo modelos de decisão multicritério. São Paulo: Atlas.

[5] Almeida AT \& Costa APCS. 2003. Aplicações com Métodos Multicritério de Apoio a Decisão. Recife: Editora Universitária da UFPE.

[6] Antonella C, Mario E, Maria GG \& Manuella LFC. 2017. EleCtRE TRIbased approach to the failure modes classification on the basis of risk parameters: An 
alternative to the risk priority number. Computers \& Industrial Engineering, 108: 100110.

[7] Aquino AT, Silva JL, Melo RM \& Silva MM. 2017. Organizational change in quality management aspects: a quantitative proposal for classification. Produção, 27: $1-15$.

[8] Backstrand J. 2007. Levels of Interaction in Supply Chain Relations. Sweden: Jönköping University.

[9] BARRATT M. 2004. Understanding of the meaning of Collaboration in the supply chain. Supply Chain Management: An International Journal, 9(1): 30-42.

[10] Brito AJ, Almeida AT \& Mota CMM. 2010. A multicriteria model for risk sorting of natural gas pipelines based on ELECTRE TRI integrating Utility Theory. European Journal of Operational Research, 200(3): 812-821.

[11] Cailloux O, Meyer P \& Mousseau V. 2012. Eliciting EleCTRE TRI category limits for a group of decision makers. European Journal of Operational Research, 223(1): 133-140.

[12] ÇAKIR S. 2017. Selecting the best supplier at a steel-producing company under fuzzy environment. International Journal of Advanced Manufacturing Technology, 88: 13451361.

[13] Calazans DLMS. 2016. Modelo de decisão multicritério para avaliação de fornecedores na gestão da alimentação coletiva em restaurantes universitários. Ph.D thesis. Universidade Federal do Rio Grande do Norte.

[14] Cao M, Vonderembse MA, Zhang Q \& Ragu-Nathan TS. 2010. Supply chain collaboration: Conceptualisation and instrument development. International Journal of Production Research, 48(22): 6613-6635.

[15] CAO M \& Zhang Q. 2011. Supply chain collaboration: Impact on collaborative advantage and firm performance. Journal of Operations Management, 29(3): 163-180.

[16] Chai J, LiU JNK \& NGai EWT. 2013. Application of decision-making techniques in supplier selection: A systematic review of literature. Expert Systems with Applications, 40(10): 3872-3885.

[17] Chan FTS, ChOng AY \& ZhOU L. 2012. An empirical investigation of factors affecting e-collaboration diffusion in SMEs. International Journal of Production Economics, 138(2): 329-344.

[18] CHANG K. 2019. A novel supplier selection method that integrates the intuitionistic fuzzy weighted averaging method and a soft set with imprecise data. Annals of Operations Research, 272: 139-157. 
[19] Corrente S, Greco S \& Slowinski R. 2016. Multiple Criteria Hierarchy Process for ELECTRE Tri methods. European Journal of Operational Research, 252(1): 191-203.

[20] Costa HG, BoAs GARV, Freitas ALP \& Gomes CFS. 2014. Modelo multicritério para avaliação e classificação da gestão organizacional: proposta e caso de uso. Produção, 24(3): 521-535.

[21] Costa HG, Mansur AFU, Freitas AlP \& Carvalho RA. 2007. ELECTRE TRI aplicado a avaliação da satisfação de consumidores. Produção, 17(2): 230-245.

[22] Costa HG, SAntafé JÚnior HPG \& HAdDAd AN. 2007. Uma contribuição do método ELECTRE TRI à obtenção da classificação de riscos industriais. Investigação Operacional, 27(2): 179-197.

[23] Costa HG, Soares AC \& Oliveira PF. 2004. Avaliação de transportadoras de materiais perigosos utilizando o método electre tri. Gestão \& Produção, 11(2): 221-229.

[24] De Felice F, Deldoost MH, Faizollahi M \& Petrillo A. 2015. Performance Measurement Model for the Supplier Selection Based on AHP. International Journal of Engineering Business Management, 7(17): 1-13.

[25] Dias LC, Antunes CH, Dantas G, Castro N \& Zamboni L. 2018. A multi-criteria approach to sort and rank policies based on Delphi qualitative assessments and ELECTRE TRI: The case of smart grids in Brazil. Omega, 76: 100-111.

[26] Dias LC \& CLÍMACo JN. 2000. ELECTRE TRI for Groups with Imprecise Information on Parameter Values. Group Decision and Negotiation, 9: 355-377.

[27] Dias L, Mousseau V, Figueira J \& Clímaco J. 2002. An aggregation/disaggregation approach to obtain robust conclusions with ELECTRE TRI. European Journal of Operational Research, 138(2): 332-348.

[28] DiCKSON GW. 1966. An analysis of vendor selection systems and decision. Journal of Purchasing, 2(1): 5-17.

[29] Doumpos M, Marinakis Y, Marinaki M \& Zopounidis C. 2009. An evolutionary approach to construction of outranking models for multicriteria classification: The case of the ELECTRE TRI method. European Journal of Operational Research, 199(2): 496-505.

[30] Ellram LM. 1990. The Supplier Selection Decision in Strategic Partnerships. Journal of Purchasing and Materials Management, 26(4): 8-14.

[31] Ensslin L, Montibeller Neto G \& Noronha SM. 2001. Apoio à decisão: Metodologias para Estruturação de Problemas e Avaliação Multicritério de Alternativas. Florianópolis: Insular. 
[32] Fontana ME \& Cavalcante CAV. 2013. Electre Tri Method Used to Storage Location Assignment into Categories. Pesquisa Operacional, 33(2): 283-303.

[33] Freitas ALP \& Silva VB. 2014. Avaliação e classificação de instituições de ensino médio: um estudo exploratório. Educação e Pesquisa, 40(1): 29-47.

[34] FREJ EA. 2017. Modelo Multicritério para Seleção de Fornecedores e Análise da Problemática de Ordenação com FITradeoff. Master's thesis. Universidade Federal de Pernambuco.

[35] Furtado GAP. 2005. Critérios de Seleção de Fornecedores para relacionamentos de Parceria: Um Estudo em Empresas de Grande Porte. Master's thesis. Universidade de São Paulo.

[36] Galo NR, Calache LDR \& CARPinetTi LCR. 2018. A group decision approach for supplier categorization based on hesitant fuzzy and ELECTRE TRI. International Journal of Production Economics, 202: 182-196.

[37] Gomes CFS, Costa HG \& BArros AP. 2017. Sensibility analysis of MCDA using prospective in Brazilian energy sector. Journal of Modelling in Management, 12(3): 475497.

[38] Gomes LC \& Kliemann Neto FJ. 2015. Métodos colaborativos na Gestão da Cadeia de Suprimentos: desafios de implementação. Revista de Administração de Empresas, 55(5): 563-577.

[39] Gomes LFAM \& Gomes CFS. 2019. Princípios e Métodos para tomada de decisão Enfoque Multicritério. $6^{\text {th }}$ ed. São Paulo: Atlas.

[40] GOVINDAN K \& JEPSEN MB. 2016. ELECTRE: A comprehensive literature review on methodologies and applications. European Journal of Operational Research, 250(1): 129.

[41] GUARNIERI P. 2012. Modelo de apoio à decisão multicritério para classificação de fornecedores em níveis de colaboração no gerenciamento da Cadeia de Suprimentos utilizando o Método Electre Tri. Ph.D thesis. Universidade Federal de Pernambuco.

[42] Guarnieri P. 2015. Síntese dos Principais Critérios, Métodos e Subproblemas da Seleção de Fornecedores Multicritério. Revista de Administração Contemporânea, 19(1): $1-25$.

[43] HA SH \& KRIShNAN R. 2008. A hybrid approach to supplier selection for the maintenance of a competitive supply chain. Expert Systems with Applications, 34(2): 1303-1311.

[44] Harrison A, Hoek RV \& SKIPWORTh H. 2014. Logistics Management and Strategy: Competing through the supply chain. $5^{\text {th }}$ ed. New York: Pearson Prentice Hall. 
[45] Ho W, XU X \& DEY PK. 2010. Multi-criteria decision making approaches for supplier evaluation and selection: A literature review. European Journal of Operational Research, 202(1): 16-24.

[46] Hudnurkar M, Rathod U \& Jakhar S K. 2016. Multi-criteria decision framework for supplier classification in collaborative supply chains Buyer's perspective. International Journal of Productivity and Performance Management, 65(5): 622-640.

[47] Hui Z, Cheng WH \& Fei ZM. 2015. Partnership Management, Supply Chain Collaboration, and Firm Innovation Performance: An Empirical Examination. International Journal of Innovation Science, 7(2): 127-138.

[48] IgOulalene I, Benyoucef L \& TiWARI MK. 2015. Novel fuzzy hybrid multi-criteria group decision making approaches for the strategic supplier selection problem. Expert Systems with Applications, 42(7): 3342-3356.

[49] KARSAK EE \& DuRsun M. 2015. An integrated fuzzy MCDM approach for supplier evaluation and selection. Computers \& Industrial Engineering, 82: 82-93.

[50] Lehoux N, D’ Amours S \& LAngevin A. 2014. Inter-firm collaborations and supply chain coordination: review of key elements and case study. Production Planning \& Control, 25(10): 858-872.

[51] Liao SH, Hu DC \& Ding LW. 2017. Assessing the influence of supply chain collaboration value innovation, supply chain capability and competitive advantage in Taiwan's networking communication industry. International Journal of Production Economics, 191:143-153.

[52] Lieggio Júnior M, GRAnemann SR, Rocha CH \& Lima Júnior OF. 2016. Assessment of the services on road transportation of dangerous goods. The Journal of Transport Literature, 10(1): 15-19.

[53] LiMA JUNIOR FR \& CARPINETTI LCR. 2015. Uma comparação entre os métodos TOPSIS e Fuzzy-TOPSIS no apoio à tomada de decisão multicritério para seleção de fornecedores. Gestão \& Produção, 22(1): 17-34.

[54] Lima Junior FR, Osiro L \& CARpinetti LCR. 2013. Métodos de decisão multicritério para seleção de fornecedores: um panorama do estado da arte. Gestão \& Produção, 20(4): 781-801.

[55] Lourenço RP \& COSTA JP. 2004. Using ELECTRE TRI outranking method to sort MOMILP nondominated solutions. European Journal of Operational Research, 153(2): 271-289.

[56] MA K, PAL R \& GuSTAFSSON E. 2019. What modelling research on supply chain collaboration informs us? Identifying key themes and future directions through a literature review. International Journal of Production Research, 57(7): 2203-2225. 
[57] Marqui AC, Moura KS \& AlCÂntara RLC. 2013. Collaborative supply chain: a conceptual model for operationalization. International Journal of Management and Decision Making, 12(3): 195-214.

[58] Matopoulos A, Vlachopoulou M, Manthou V \& Manos B. 2007. A conceptual framework for supply chain collaboration: empirical evidence from the agri-food industry. Supply Chain Management: An International Journal, 12(3): 177-186.

[59] Miranda CMG \& Almeida AT. 2003. Avaliação de pós-graduação com método ELECTRE TRI - o caso de Engenharias III da CAPES. Produção, 13(3): 101-112.

[60] Moharana HS, Murty JS, Senapati SK \& Khuntia K. 2012. Coordination, Collaboration and Integration for Supply Chain Management. International Journal of Interscience Management Review, 2(2): 46-50.

[61] Mousseau V, Figueira J \& Naux JP. 2001. Using assignment examples to infer weights for ELECTRE TRI method: Some experimental results. European Journal of Operational Research, 130(2): 263-275.

[62] Mousseau V \& Slowinski R. 1998. Inferring an ELECTRE TRI Model from Assignment Examples. Journal of Global Optimization, 12(2): 157-174.

[63] Mousseau V, Slowinski R \& Zielniewicz P. 1999. ElECTRE TRI 2.0a: Methodological Guide and User's Manual. Document Du Lamsade $\mathrm{N}^{\circ} 111$, Université Paris-Dauphine.

[64] Mousseau V, Slowinski R \& Zielniewicz P. 2000. A user-oriented implementation of the ELECTRE-TRI method integrating preference elicitation support. Computers \& Operations Research, 27(7-8): 757-777.

[65] Norese MF \& Carbone V. 2014. An Application of ELECTRE Tri to Support Innovation. Journal of Multi-criteria Decision Analisys, 21(1-2): 77-93.

[66] Pal O, Gupta AK \& Garg RK. 2013. Supplier Selection Criteria and Methods in Supply Chains: A Review. International Journal of Economics and Management Engineering, 7(10): 2667-2673.

[67] Panahifar F, Byrne PJ, Salam MA \& Heavey C. 2018. Supply chain collaboration and firm's performance: The critical role of information sharing and trust. Journal of Enterprise Information Management, 31(3): 358-379.

[68] Ralston PM, Richey RG \& GRAwe SJ. 2017. The past and future of supply chain collaboration: a literature synthesis and call for research. International Journal of Logistics Management, 28(2): 508-530.

[69] RAMEZANiAn R. 2019. Estimation of the profles in posteriori ELECTRE TRI: A mathematical programming model. Computers \& Industrial Engineering, 128: 47-59. 
[70] Rodriguez JMM. 2017. Modelo de decisão multicritério para Seleção de Fornecedores de equipamentos laboratoriais para pesquisa agropecuária. Master's thesis. Universidade Federal de Pernambuco.

[71] RoY B. 1996. Multicriteria methodology for decision aiding. Kluwer Academic Publishers.

[72] Salam MA. 2017. The mediating role of supply chain collaboration on the relationship between technology, trust and operational performance: An empirical investigation. Benchmarking: An International Journal, 24(2): 298-317.

[73] Sánchez-Lozano JM, Antunes CH, García-Cascales MS \& Dias LC. 2014. GIS-based photovoltaic solar farms site selection using ELECTRE-TRI: Evaluating the case for Torre Pacheco, Murcia, Southeast of Spain. Renewable Energy, 66: 478-494.

[74] SÁnchez-Lozano JM, García-Cascales MS \& LAmata MT. 2016. Comparative TOPSIS-ELECTRE TRI methods for optimal sites for photovoltaic solar farms. Case study in Spain. Journal of Cleaner Production, 127(20): 387-398.

[75] Sarkar S, Pratihar DK \& Sarkar B. 2018. An integrated fuzzy multiple criteria supplier selection approach and its application in a welding company. Journal of Manufacturing Systems, 46: 163-178.

[76] Simatupang TM \& SRIDharan R. 2002. The Collaborative Supply Chain. International Journal of Logistics Management, 13(1): 15-30.

[77] Simões RG. 2013. Aplicação do ELECTRE TRI na Classificação de Fornecedores de Indústria Automotiva. Master's thesis. Universidade Federal Fluminense.

[78] Singh PJ \& Power D. 2009. The nature and effectiveness of collaboration between firms, their customers and suppliers: a supply chain perspective. Supply Chain Management: An International Journal, 14(3): 189-200.

[79] SoOsAy CA \& HyLAND P. 2015. A decade of supply chain collaboration and directions for future research. Supply Chain Management: An International Journal, 20(6): 613-630.

[80] Spekman RE, Kamauff JR JW \& Myhr N. 1998. An empirical investigation into supply chain management: a perspective on partnerships. Supply Chain Management: An International Journal, 3(2): 53-67.

[81] Sultana I, Ahmed I \& AzeEm A. 2015. An integrated approach for multiple criteria supplier selection combining Fuzzy Delphi, Fuzzy AHP \& Fuzzy TOPSIS. Journal of Intelligent \& Fuzzy System, 29(4): 1273-1287.

[82] Szajubok NK, Alencar LH \& Almeida AT. 2006. Modelo de gerenciamento de materiais na construção civil utilizando avaliação multicritério. Produção, 16(2): 303-318. 
[83] Szajubok NK, Mota CMM \& Almeida AT. 2006. Uso do Método Multicritério ELECTRE TRI para classificação de estoques na construção civil. Pesquisa Operacional, 26(3): 625-648.

[84] Trojan F \& Morais DC. 2012. Using Electre Tri to Support Maintenance of Water Distribution Networks. Pesquisa Operacional, 32(2): 423-442.

[85] Viana JC \& AlenCAR LH. 2012. Metodologias para seleção de fornecedores: Uma Revisão da Literatura. Produção, 22(4): 625-636.

[86] Weber CA, Current JR \& Benton WC. 1991. Vendor selection criteria and methods. European Journal of Operational Research, 50(1): 2-18.

[87] YAdAV V \& Sharma MK. 2015. Multi-criteria decision making for supplier selection using fuzzy AHP approach. Benchmarking: An International Journal, 22(6): 1158-1174.

[88] YAdAV V \& Sharma MK. 2016. Multi-criteria supplier selection model using the analytic hierarchy process approach. Journal of Modelling in Management, 11(1): 326-354.

[89] Yildiz A \& YAYLA AY. 2015. Multi-criteria decision-making methods for supplier selection: A literature Review. South African Journal of Industrial Engineering, 26(2): 158-177.

[90] YILDIZ A \& YAYLA AY. 2017. Application of fuzzy TOPSIS and generalized Choquet integral methods to select the best supplier. Decision Science Letters, 6(2): 137-150.

[91] YU W. 1992. ELECTRE TRI - Aspects methodologiques et guide d'utilisation. Document du Lamsade 74, Université Paris-Dauphine.

[92] Zacharia ZG, Nix NW \& Lusch RF. 2009. An Analysis of Supply Chain Collaborations and their effect operformance outcomes. Journal of Business Logistics, 30(2): 101-123.

[93] Zhang Q \& CAO M. 2018. Exploring antecedents of supply chain collaboration: Effects of culture and interorganizational system appropriation. International Journal of Production Economics, 195: 146-157.

[94] Zheng J, Takougang SAM, Mousseau V \& Pirlot M. 2014. Learning criteria weights of an optimistic ELECTRE TRI sorting rule. Computers \& Operations Research, 49: $28-40$.

\section{How to cite}

Gonçalves ATP, Araújo MVP, Mól ALR \& Rocha FAF. 2021. Application of the ELECTRE TRI method for supplier classification in supply chains. Pesquisa Operacional, 41: e229708. doi: 10.1590/01017438.2021.041.00229708. 